\title{
LA PROTECCIÓN PENAL DE LA VIDA, SALUD E INTEGRIDAD FÍSICA DE LOS TRABAJADORES ANTE EL SARS-COV-2 Y LA PANDEMIA DE COVID-19 ${ }^{1}$
}

\author{
Virxilio Rodríguez Vázquez*
}

Recibido: junio 2020. Aceptado: octubre 2020

1 El presente trabajo se inscribe en el proyecto de investigación "Responsabilidad penal de personas físicas y jurídicas en el ámbito empresarial, económico, laboral y de los mercados (II)" (Referencia: DER201458546-R, Ministerio de Economía y Competitividad), del que es investigador principal el Prof. Dr. Dr. h. c. mult. Diego-Manuel Luzón Peña, Catedrático de Derecho Penal de la Universidad de Alcalá de Henares, así como también en el proyecto de investigación "Principios y garantías penales: sectores de riesgo" (Referencia: DER2016-76715-R, Ministerio de Ciencia e Innovación) del que es investigador principal el Prof. Dr. Dres. h. c. Miguel Díaz y García Conlledo, Catedrático de Derecho Penal de la Universidad de León, y de cuyos equipos de trabajo formo parte. Quisiera agradecer a los editores y evaluadores de la Revista Estudios Penales y Criminológicos sus observaciones y sugerencias que, sin lugar a dudas, han contribuido a mejorar este trabajo.

* Profesor Contratado Doctor de Derecho penal (acred. Profesor Titular). ORCID ID: 0000-0002-0240-2631 Facultad de Derecho. Universidad de Vigo. Campus Universitario s/n, 32004, Ourense, España. Email: virxilio@uvigo.es. 
Resumen: El 11 de marzo de 2020 la OMS declaró la alerta por pandemia internacional debido al SARS-CoV-2 y la enfermedad derivada, COVID-19. El Gobierno español decretó el estado de alarma por crisis sanitaria el 14 de marzo de 2020. Tras sucesivas prórrogas, el estado de alarma finalizará el día 9 de mayo de 2021. No obstante, el virus no está erradicado, permaneciendo el riesgo de contagio, de desarrollo de la enfermedad y, consecuentemente, la necesidad de mantener medidas estrictas de protección.

En este contexto, este trabajo plantea dos preguntas. La primera es si la infracción de normas de prevención de riesgos laborales derivados del SARS-CoV-2 y la enfermedad asociada, puede dar lugar a responsabilidad penal. En caso de que la respuesta sea afirmativa, la segunda pregunta sería quién puede ser responsable penalmente de dicha infracción.

Palabras clave: SARS-CoV-2, COVID-19, riesgos laborales, prevención, responsabilidad penal.

Abstract: On March 11, 2020, the WHO declared the international pandemic alert due to SARS-CoV-2 and the derived disease, COVID-19. The Spanish Government decreed the state of alarm due to a health crisis on March 14, 2020, which after successive extensions will end on May 9, 2021. However, the virus has not been eradicated, remaining the risk of contagion and the development of the disease and, consequently, the need to maintain strict protection measures.

In this context, this work raises two questions. The first is whether the violation of regulations for the prevention of occupational risks derived from SARS-CoV-2 and the associated disease, may give rise to criminal liability. If the answer is affirmative, the second question would be who can be held criminally responsible for said infraction. Keywords: SARS-CoV-2, COVID-19, risks at work, prevention, criminal liability.

\section{Introducción}

La protección penal de la vida, salud e integridad física de los trabajadores encuentra acomodo en el Derecho positivo español a través de los arts. 316 y 317 Código Penal (CP), en los que se contemplan los delitos relativos a la 
infracción de las normas de prevención de riesgos laborales en su modalidad dolosa e imprudente respectivamente. El art. $316 \mathrm{CP}$ dispone, "los que con infracción de las normas de prevención de riesgos laborales y estando legalmente obligados, no faciliten los medios necesarios para que los trabajadores desempeñen su actividad con las medidas de seguridad e higiene adecuadas, de forma que pongan así en peligro grave su vida, salud o integridad física, serán castigados con las penas de prisión de seis meses a tres años y multa de seis a doce meses". Por su parte, el art. 317 CP establece, "cuando el delito a que se refiere el artículo anterior se cometa por imprudencia grave, será castigado con la pena inferior en grado".

Sin lugar a dudas, estos artículos presentan numerosos problemas en relación con los diferentes elementos típicos. En primer lugar, cuestiones relativas a la delimitación del sujeto activo, respecto al que se plantea si se trata de un delito común o especial y, en su caso, cuál es el círculo de personas que pueden verse abarcadas por el tipo. Otra de las cuestiones problemáticas que guarda relación directa con la anterior, es la relativa a la conducta típica. En este sentido se discute si se trata de un delito de omisión o no, si se puede calificar de una norma penal en blanco y, en este caso, a qué normativa extrapenal se debe acudir para integrar la conducta típica (leyes, reglamentos, pero ¿también convenios colectivos?). En cuanto al resultado, el tipo parece exigir un peligro para la vida y salud de los trabajadores, lo que nos obliga a tratar de concretar el nivel de peligro exigido y, a continuación, a delimitar este delito respecto al homicidio y lesiones cuando se produzca alguno de estos resultados. Es decir, dirimir las cuestiones concursales que en general y, en este caso en particular, presentan no pocas dificultades.

El análisis teórico de estos tipos penales y su aplicación práctica alcanza mayor complejidad, si cabe, en el contexto de crisis sanitaria provocada por la expansión del SARS-CoV-2 y el desarrollo de la enfermedad asociada, 
COVID-19; especialmente, a partir del momento en que la OMS declara la alerta por pandemia internacional, el día 11 de marzo de 2020, y el posterior decreto de estado de alarma por parte del Gobierno de España, el día 14 de marzo de 2020.

Es en este contexto en el que en este trabajo se plantean dos grandes preguntas. La primera de ellas es si la infracción de normas de prevención de riesgos laborales derivados de la enfermedad de COVID-19 puede dar lugar a responsabilidad penal. En caso de que la respuesta sea afirmativa, la segunda pregunta sería quién puede ser responsable penalmente de dicha infracción.

El abordaje de la primera pregunta pasa necesariamente por aclarar si la enfermedad de COVID-19 puede ser considerada un riesgo laboral y, por lo tanto, abarcado por las normas de prevención o no. Para aclarar este punto creo necesario aproximarse, aunque sea someramente, al SARSCoV-2 y a la enfermedad vinculada al virus, COVID-19. Es decir, analizar su origen, los mecanismos de transmisión, la forma en que afecta a la salud y a la vida de las personas, así como los medios para hacerle frente. Pues bien, esta aproximación ha de partir de la premisa de que el estado de cosas existente sobre el tema es cambiante, plagado de incógnitas y con no pocas informaciones contradictorias. No obstante, ya hay certezas que deben ser expuestas y que tienen relevancia para las preguntas que planteamos en el presente estudio. Adelanto que de este análisis se deriva que el virus y la enfermedad asociada pueden ser considerados riesgos laborales $y$, por tanto, deben ser tenidos en cuenta por las normas de prevención de riesgos laborales pudiendo dar lugar a responsabilidad penal. Esta constatación nos va a permitir transitar hacia la segunda pregunta que tiene que ver con la identificación de los sujetos a los que se les podrá exigir responsabilidad penal por incumplimiento de las medidas laborales de prevención vinculadas al SARS-CoV-2 y a la enfermedad COVID-19. 


\section{Aproximación a la etiología, características y evolución del SARS-COV-2 y de la COVID-19. Análisis acerca de su poten- cial incidencia en actividades laborales.}

Los coronavirus son una familia de virus que se dan tanto en animales como en humanos. Entre los coronavirus que afectan a humanos, un total de siete, la mayoría de ellos, en concreto cuatro, causan síntomas de resfriado común que, por tanto, podemos considerar leves siendo pocas las probabilidades de que lleguen a producir infecciones graves de las vías respiratorias, como la neumonía, y, por tanto, causar la muerte de una persona. Los tres restantes son coronavirus que, sin embargo, pueden llegar a causar infecciones respiratorias graves e incluso mortales.

En orden cronológico, el primero de ellos, identificado en el año 2002, fue el SARS-CoV-1. Las siglas corresponden a su denominación en inglés, severe acute respiratory sindrome coronavirus, cuya traducción sería coronavirus del síndrome respiratorio agudo severo. Dicha denominación responde al principal efecto que este virus causa en las personas y es, por sí misma, muy representativa. El número 1 es un reciente añadido para distinguirlo precisamente del SARS-CoV-2, al que me referiré más adelante. Como una neumonía atípica emerge en Foshan, provincia de Guangdong, en China, en noviembre de 2002. En febrero y marzo de 2003, los contagios por esta enfermedad se extienden a Hong Kong y, posteriormente Vietnam, Singapur, Canadá hasta llegar en junio de ese mismo año a treinta y dos países de los cinco continentes, afectando a más de 8000 personas y causando 900 muertes, convirtiéndose así en la primera pandemia del siglo $\mathrm{XXI}^{2}$. En España se declaró oficialmente un caso pero la

2 ABRAHAM, T., Twenty-first century plague. The story of SARS, Hong Kong, 2004, p. 2; PEIRIS, J. S.M./YUEN, K. Y./OSTERHAUS, A./STÖHR, K., "The severe acute respiratory sindrome", en $N$ Engl J Med 349;25, December 18, 2003, pp. 2431-41, p. 2431. Sobre la expansión del virus, véase HERNÁNDEZ MARTÍNEZ, G., "SARS: epidemiología y mecanismos de transmisión”, en Med Intensiva 2003; 27 (10), pp. 686-91, pp. 686 ss. 
información sobre el mismo es escasa ${ }^{3}$. Se trata de un virus que cruzó la barrera entre especies, de animales a humanos, produciéndose los primeros contagios humanos en personas que trabajaban en el comercio de animales salvajes en la provincia de Guangdong, así como en personas que manipulaban animales utilizados para comidas exóticas ${ }^{4}$. Los síntomas que desarrollan las personas infectadas son, inicialmente, fiebre, mialgia, malestar general, además de tos. Siendo la vía primaria de transmisión el contacto de ojos, boca o nariz con gotitas en suspensión procedentes de una persona infectada, al estornudar, al toser, al hablar, los estudios indicaron que el SARS-CoV-1 era menos transmisible de lo que inicialmente se pensaba, debido en buena medida a que, aunque existieron casos de trasmisión de la enfermedad por personas asintomáticas o con muy baja carga viral, esto era muy poco frecuente y no contribuyó a la expansión de la enfermedad entre humanos. Además, la transmisión entre contactos casuales o en el ámbito de relaciones sociales cotidianas también se considera muy poco común, produciéndose ocasionalmente en casos de contactos cercanos en el lugar de trabajo y en algunos medios de transporte ${ }^{5}$.

3 VAQUÉ RAFART, J., "Síndrome respiratorio agudo grave (SARS)", en An Pediatr (Barc) 2005; 62 (Supl 1), pp. 6-11, p. 9.

4 VAQUÉ RAFART, J., "Síndrome respiratorio agudo grave (SARS)", en An Pediatr (Barc) 2005; 62 (Supl 1), pp. 6-11, p. 9, señala que "el SARS$\mathrm{CoV}$ ha sido identificado en el gato civeta (Viverra civetta) y otros animales como el perro mapache (Paguna larvata), obtenido en un mercado de animales vivos de Shenzen (Guangdong), que son indígenas de la zona, y también en trabajadores del mismo mercado, así como en comerciantes de animales que no presentaron síntomas de la enfermedad. Los primeros casos en humanos ocurrieron en trabajadores de restaurante y empresas de alimentación de la zona de Guangdong donde se consume el gato civeta; seguramente se infectaron al manipular o sacrificar el animal y no a través del consumo. La impresión general es que los animales en los que se ha detectado el virus constituyen reservorios transitorios u ocasionales y que el hábitat permanente de momento se desconoce".

5 PEIRIS, J.S.M./YUEN, K.Y./OSTERHAUS, A./STÖHR, K., "The severe acute respiratory sindrome", en $N$ Engl J Med 349;25, December 18, 2003, pp. 2431-41, p. 2433. 
Las personas más vulnerables a la enfermedad y, por tanto, con una mayor probabilidad de un pronóstico peor, fueron las personas mayores de 65 años (en estos pacientes la letalidad es superior al $50 \%)^{6}$, así como personas que sufrían una enfermedad como diabetes o problemas coronarios. Por su parte, la enfermedad se demostró que tenía una capacidad de incidencia bajísima en menores de 12 años ${ }^{7}$. Ante la ausencia de vacuna, las medidas de prevención que se consideraron adecuadas para evitar el contagio y, en consecuencia, el avance de la enfermedad fueron la detección temprana de pacientes infectados en hospitales y en centros educativos para proceder a su aislamiento y la puesta en cuarentena de personas con las que el paciente mantuvo contacto, además de restricciones de la movilidad, medidas higiénicas, distanciamiento social, entre otras ${ }^{8}$. Todas estas medidas lograron contener la expansión del virus y la enfermedad en un período comprendido, según la OMS, entre el 22 de noviembre de 2002, fecha de aparición del primer caso, y el 11 de julio de 2003, fecha del último caso, con una evolución de la curva epidémica que llegó a presentar su pico máximo el día 28 de marzo de 2003, con 140 casos, y con una letalidad global del 9,6\% ${ }^{9}$. Finalizada la epidemia, en los años siguientes se notificaron casos aislados, la mayoría asociados a contagios derivados de manipulaciones en laboratorios ${ }^{10}$.

6 VAQUÉ RAFART, J., "Síndrome respiratorio agudo grave (SARS)", en An Pediatr (Barc) 2005; 62 (Supl 1), pp. 6-11, p. 8.

7 VAQUÉ RAFART, J., "Síndrome respiratorio agudo grave (SARS)", en An Pediatr (Barc) 2005; 62 (Supl 1), pp. 6-11, p. 8, "la enfermedad afecta a todas las edades, pero un hecho ha llamado poderosamente la atención: en niños y adolescentes se han detectado muy pocos casos; en la epidemia de Hong Kong no llegaron al 10\% del total".

8 PEIRIS, J.S.M./YUEN, K.Y./OSTERHAUS, A./STÖHR, K., "The severe acute respiratory sindrome", en $N$ Engl J Med 349;25, December 18, 2003, pp. 2431-41, p. 2439.

9 VAQUÉ RAFART, J., "Síndrome respiratorio agudo grave (SARS)", en An Pediatr (Barc) 2005; 62 (Supl 1), pp. 6-11, pp. 9 s.

10 VAQUÉ RAFART, J., "Síndrome respiratorio agudo grave (SARS)", en An Pediatr (Barc) 2005; 62 (Supl 1), pp. 6-11, p. 6. 
El segundo fue el MERS-CoV, identificado por primera vez en septiembre del año 2012 en una persona de Arabia Saudí que presentaba una neumonía además de afectación de otros órganos. Las siglas con las que se denomina a este nuevo coronavirus hacen referencia a su origen geográfico, en inglés, middle east respiratory syndrome, traducido en español como síndrome respiratorio de Oriente Medio. La mayoría de los casos han ocurrido en países de Oriente Medio, siendo los casos que se presentan fuera de estos territorios, casos importados con antecedentes de viaje en estos países o con contactos cercanos con casos confirmados ${ }^{11}$. Entre septiembre de 2012 y enero de 2017, la OMS confirmó un total de 1879 casos en 27 países y, al menos, 659 muertes. Con una letalidad del $35 \%$, la gran mayoría de los casos (el 80\% del total) se presentan en Arabia Saudí1 ${ }^{12}$. Todos los estudios parecen confirmar que el salto entre especies se produce desde los dromedarios a personas que, generalmente por su trabajo, tienen contactos con estos animales. Sin estar clara la vía de trasmisión, pueden incluir las vías respiratorias, contacto con secreciones corporales e, incluso, el consumo de productos alimenticios procedentes de este animal, como carne cruda o leche no pasteurizada ${ }^{13}$. La transmisión entre humanos es

11 MAESTRE NARANJO, M.A./DIETL SAGÜÉS, M./OLIVARES ROMÁN, S./GARCÍA ARCONES, R./GÓMEZ CREGO, R./RODRÍGUEZ DE LA PINTA/M.L., "Actuación de un servicio de prevención de riesgos laborales para la atención a casos sospechosos de enfermedad respiratoria por coronavirus (MERS-CoV): a propósito de un caso", en Med Segur Trab, 2017; 63 (247), pp. 93-102, p. 95.

12 ARABI, Y.M./BALKHY, H.H./HAYDEN, F.G./BOUCHAMA, A./ LUKE, T./BAILLIE, K./AL-OMARI, A./HAJEER, A.H./SENGA, M./DENISON, M./NGUYEN-VAN-TAM, J.S./SHINDO, N./ BERMINGHAM, A./CHAPPELL, J.D./VAN KERKHOVE, M.D./ FOWLER, R.A., "Middle East Respiratory Syndrome", en $N$ Engl $J$ Med 376;6, February 9, 2017, pp. 584-594, p. 584.

13 ARABI, Y.M./BALKHY, H.H./HAYDEN, F.G./BOUCHAMA, A./ LUKE, T./BAILLIE, K./AL-OMARI, A./HAJEER, A.H./SENGA, M./DENISON, M./NGUYEN-VAN-TAM, J.S./SHINDO, N./ BERMINGHAM, A./CHAPPELL, J.D./VAN KERKHOVE, M.D./ 
infrecuente fuera de centros hospitalarios pero se han documentado algunos casos de contagio entre personas que guardaban un estrecho contacto, generalmente conviviendo en el mismo domicilio, no confirmándose ninguno de estos casos fuera de Arabia Saudí14. La mayor parte de casos graves de MERS-CoV se dan en adultos de más de 50 años y que padecen una enfermedad de base como diabetes, hipertensión, enfermedad cardíaca, obesidad, una enfermedad respiratoria crónica, insuficiencia renal, cáncer o personas sometidas a un tratamiento inmunodepresivo, siendo leves o incluso no presentando síntomas, las personas más jóvenes, sin enfermedades de base, y muy poco comunes los casos de niños infectados ${ }^{15}$. En España se sospechó de dos casos en noviembre de 2013, en concreto se trataba de dos personas que habían realizado una peregrinación a La Meca y presentaban síntomas y una clínica compatible con la enfermedad, sin embargo las pruebas realizadas no lograron confirmarlos ${ }^{16}$. El primer caso confirmado en España se produjo, no obstante, en noviembre de 2013. Se trataba de una mujer de 61 años

FOWLER, R.A., "Middle East Respiratory Syndrome", en $N$ Engl $J$ Med 376;6, February 9, 2017, pp. 584-594, p. 585.

14 ARABI, Y.M./BALKHY, H.H./HAYDEN, F.G./BOUCHAMA, A./ LUKE, T./BAILLIE, K./AL-OMARI, A./HAJEER, A.H./SENGA, M./DENISON, M./NGUYEN-VAN-TAM, J.S./SHINDO, N./ BERMINGHAM, A./CHAPPELL, J.D./VAN KERKHOVE, M.D./ FOWLER, R.A., "Middle East Respiratory Syndrome", en $N$ Engl $J$ Med 376;6, February 9, 2017, pp. 584-594, p. 585.

15 ARABI, Y.M./BALKHY, H.H./HAYDEN, F.G./BOUCHAMA, A./ LUKE, T./BAILLIE, K./AL-OMARI, A./HAJEER, A.H./SENGA, M./DENISON, M./NGUYEN-VAN-TAM, J.S./SHINDO, N./ BERMINGHAM, A./CHAPPELL, J.D./VAN KERKHOVE, M.D./ FOWLER, R.A., "Middle East Respiratory Syndrome", en $N$ Engl $J$ Med 376;6, February 9, 2017, pp. 584-594, p. 587.

16 MAESTRE NARANJO, M.A./DIETL SAGÜÉS, M./OLIVARES ROMÁN, S./GARCÍA ARCONES, R./GÓMEZ CREGO, R./RODRÍGUEZ DE LA PINTA, M.L., "Actuación de un servicio de prevención de riesgos laborales para la atención a casos sospechosos de enfermedad respiratoria por coronavirus (MERS-CoV): a propósito de un caso", en Med Segur Trab, 2017; 63 (247), pp. 93-102, p. 95. 
residente en España que había regresado de un viaje a Arabia Saudí, Medina y La Meca, ingresando el 1 de noviembre en el Hospital Universitario Puerta de Hierro, con fiebre, tos y diagnóstico de neumonía, confirmándose a través de pruebas de microbiología el día 5 de noviembre que se trataba de un caso de MERS-CoV ${ }^{17}$. La expansión de este virus en España no se produjo por las razones ya señaladas, pero la nula incidencia sobre el propio personal sanitario y otros pacientes se debe, sin duda alguna, a las rápidas y efectivas medidas de seguridad adoptadas en el centro hospitalario ${ }^{18}$.

El tercer coronavirus es el llamado SARS-CoV-2. Antes ya se ha explicado el significado de estas siglas, y si se repiten aquí es porque, como veremos, se trata de un coronavirus muy similar a aquel. Para distinguirlos en su denominación se añade el número 2. Según la Organización Mundial de la Salud (en adelante, OMS), el 31 de diciembre de 2019, su sección en China recibió el informe de las autoridades del gobierno de la República Popular de China de que en la ciudad de Wuhan, provincia de Hubei, se había detectado un caso de neumonía de etiología desconocida. Hasta el 3 de enero de 2020 se identifican un total de 44 pacientes que sufren esta misma neumonía. El 7 de enero las autoridades Chinas logran aislar en laboratorio un nuevo coronavirus y el día 12 de enero comparten la secuencia genética para que otros países

17 MAESTRE NARANJO, M.A./DIETL SAGÜÉS, M./OLIVARES ROMÁN, S./GARCÍA ARCONES, R./GÓMEZ CREGO, R./RODRÍGUEZ DE LA PINTA, M.L., "Actuación de un servicio de prevención de riesgos laborales para la atención a casos sospechosos de enfermedad respiratoria por coronavirus (MERS-CoV): a propósito de un caso", en Med Segur Trab, 2017; 63 (247), pp. 93-102, p. 96.

18 Esta respuesta ha quedado suficientemente documentada en, entre otros, MAESTRE NARANJO, M.A./DIETL SAGÜÉS, M./OLIVARES ROMÁN, S./GARCÍA ARCONES, R./GÓMEZ CREGO, R./ RODRÍGUEZ DE LA PINTA, M.L., "Actuación de un servicio de prevención de riesgos laborales para la atención a casos sospechosos de enfermedad respiratoria por coronavirus (MERS-CoV): a propósito de un caso", en Med Segur Trab, 2017; 63 (247), pp. 93-102, pp. 96 ss. 
puedan desarrollar kits de diagnóstico. Entre el 11 y el 12 de enero, la Comisión Nacional de Salud de China comunica a la OMS que el brote infeccioso tiene su origen en el mercado de pescado de Huanan, en la ciudad de Wuhan. En los días siguientes, 13, 15 y 20 de enero, Tailandia, Japón y la República de Corea, confirman, respectivamente, la existencia del primer caso importando de China en sus territorios. A día 20 de enero, alrededor de 278 casos estaban confirmados en China, en concreto en las provincias de Hubei y Guangdong, y en los municipios de Pekín y Shanghai. Los casos se incrementan a diario, confirmándose el 23 de enero el primer caso importado en los Estados Unidos. En esta fecha también se constata el contagio de humanos a humanos. El 28 de enero se confirman los primeros casos en Europa, en concreto 3 en Francia y 1 en Alemania. El día 29 de enero la OMS propone la denominación para el nuevo virus, "2019-nCoV", correspondiendo, en inglés, a "novel coronavirus". El 31 de enero, coincidiendo con la confirmación de los dos primeros casos en Italia, la OMS declara que el brote era una emergencia de salud pública de interés internacional. En esta fecha, el Comité de Emergencia constituido ad hoc para el 2019-nCoV cree todavía posible impedir la expansión del virus si los países adoptan medidas firmes para una detección temprana de la enfermedad, aislamiento, trazabilidad de los casos, distanciamiento social. Entonces las cifras de personas que habían sido infectadas en el mundo ascendía a 9826, y 213 muertes en China. El 1 de febrero, el informe de seguimiento de la enfermedad emitido por la OMS revela quizá el principal error en la gestión de la crisis que explicaría, en buena medida, la rápida expansión geográfica y en número de personas afectadas por el virus. Ese informe señala que "la OMS es consciente de la posibilidad de que el 2019-nCoV se transmita por una persona infectada antes de que ésta desarrolle síntomas. (...) La infección sin síntomas podría ser algo raro y la transmisión de una persona asintomática a otra es muy extraña como ocurre con otros coronavirus, como hemos visto con el 
coronavirus del síndrome respiratorio de oriente medio. Por tanto, es probable que la trasmisión por asintomáticos no sea la principal vía de trasmisión. Las personas que presentan síntomas pueden trasmitir el virus más rápidamente a través de tos y estornudos"19. El 11 de febrero, la OMS acorta el nombre para la nueva enfermedad, pasando a denominarse COVID-19, es decir, coronavirus disease 2019, que se puede traducir por enfermedad del coronavirus 2019. A partir del 21 de febrero se identifica con el término COVID-19 la enfermedad causada por el virus del SARS-CoV-2. Desde esta fecha comienzan a aparecer estudios sobre el origen del virus, su pervivencia en superficies, seguridad alimentaria, el papel de la contaminación ambiental, etc. El 26 de febrero, por primera vez desde que se identificó el primer caso en China, el número de nuevos contagios es mayor fuera de China que en este país. El número de personas infectadas a esa altura en todo el mundo era de 81.109. En su informe de 28 de febrero, se dice literalmente que "la OMS ha publicado un boletín de consejos actualizado sobre tráfico internacional, y continúa siendo contraria a la aplicación de cualquier restricción para viajar o comerciar en relación con el actual brote del COVID-19" 20 . El día 8 de marzo el virus ha infectado a personas de más de 100 países, y la OMS hace un llamamiento general a que todos los Estados preparen sus sistemas sanitarios para dar respuesta a la enfermedad. El 10 de marzo, cuando un número importante de países han adoptado restricciones

19 World Health Organization (WHO), Novel Coronavirus (2019-nCoV). Situation Report-12, 1 February 2020, https://www.who.int/docs/default-source/coronaviruse/situation-reports/20200201-sitrep-12-ncov. pdf?sfvrsn=273c5d35_2 (consultado en: 10/05/2020).

20 World Health Organization (WHO), Coronavirus disease 2019 (COVID-19). Situation Report-39, 28 February 2020, https://www.who.int/ docs/default-source/coronaviruse/situation-reports/20200228-sitrep39-covid-19.pdf?sfvrsn=5bbf3e7d_4 (consultado en: 10/05/2020). Dada la importancia del texto, lo transcribo literalmente tal y como aparece en el informe, en inglés: "WHO has published updated advice for international traffic, and continues to recommend against the application of any travel or trade restrictions in relation to the current COVID-19 outbreak". 
en los desplazamientos internacionales, especialmente en vuelos internacionales, la OMS reitera su posición del día 28 de febrero, señalando que "las medidas que restringen el movimiento de personas durante este brote deberían ser proporcionadas al riesgo de salud pública, cortas en su duración y revisadas en función de la información que se vaya teniendo sobre el virus" ${ }^{21}$. Finalmente, el día 11 de marzo, la OMS declara la alerta por pandemia internacional. En todo el mundo hay 118.319 casos confirmados de pacientes contagiados, 4.292 muertes. En Italia se contabilizan a esa altura 631 muertes y en España 36. El SARS-CoV-2 se contagia de persona a persona principalmente a través de la inhalación de gotículas que son expulsadas cuando una persona infectada tose o estornuda. El alcance de estas gotículas se considera que no es superior a dos metros. Es sabido, no obstante, que la transmisión se puede producir por inhalación de aerosol (virus suspendido en el aire) especialmente en ciertas actividades como la intubación o desintubación en centros hospitalarios, pero hay estudios que señalan la posibilidad de que el virus permanezca suspendido en el aire y, por tanto, pueda ser inhalado en espacios cerrados (p. ej. ascensores, oficinas, aulas) durante un tiempo de como mínimo 3 horas ${ }^{22}$. También puede persistir durante horas e incluso días en superficies de cartón, papel, plástico, así como superficies metálicas, de modo que el contacto con las mismas, si previamente han sido depositarias del virus por parte de una persona infectada, puede constituir también una vía de contagio ${ }^{23}$.

21 World Health Organization (WHO), Coronavirus disease 2019 (COVID-19). Situation Report-50, 10 March 2020, https://www.who.int/ docs/default-source/coronaviruse/situation-reports/20200310-sitrep50-covid-19.pdf?sfvrsn=55e904fb_2 (consultado en: 10/05/2020).

22 VAN DOREMALEN, N./MORRIS, D.H./HOLBROOK, M.G. et al., "Aerosol and surface stability of SARS-CoV-2 as Compared with SARS-CoV-1", en $N$ Engl J Med 382;16, April 16, 2020, pp. 1-4, p. 1.

23 VAN DOREMALEN, N./MORRIS, D.H./HOLBROOK, M.G. et al., "Aerosol and surface stability of SARS-CoV-2 as Compared with SARS-CoV-1", en $N$ Engl J Med 382;16, April 16, 2020, pp. 1-4, pp. 1 ss. 
Los factores de riesgo de que la COVID-19 produzca complicaciones son la edad, por encima de 65 años, las enfermedades cardiovasculares, enfermedades respiratorias crónicas, hipertensión, diabetes y obesidad, desarrollando una enfermedad leve o moderada el $81 \%$ de los pacientes, una enfermedad severa el 14\% y produciéndose una enfermedad crítica en el 5\% de los pacientes infectados ${ }^{24}$. En todo caso, la propia OMS advierte que el riesgo de que se manifieste una enfermedad grave se incrementa gradualmente a partir de los 40 años $^{25}$. En cuanto a los síntomas, los más habituales son fiebre, tos seca y cansancio, pero también se han relacionado otros como dolores y molestias inespecíficos, congestión nasal, dolor de cabeza, conjuntivitis, dolor de garganta, diarrea, perdida del gusto o el olfato, erupciones cutáneas, cambios del color de los dedos de manos o pies. Hoy en día todavía no existe una terapia curativa siendo diversos los medicamentos que se han tratado de utilizar en pacientes que presentan un cuadro clínico grave ${ }^{26}$.

El SARS-CoV-2, identificado en 2019, presenta muchas similitudes con el SARS-CoV-1, identificado en 2002. Para empezar ambos son coronavirus zoonóticos. El salto de la barrera entre especies se produce, por lo que todo parece indicar, en personas que se dedican a la manipulación de animales salvajes en mercados en los que se comercia con este tipo de fauna. Se trata, además, de dos mercados localizados en China. El momento temporal de aparición y expansión es coincidente, otoño, y el desarrollo de la curva epidemiológica también, con picos en ambos casos en los meses de marzo

24 GANDHI, R./LYNCH, J./DEL RIO, C., "Mild or Moderate Covid-19", en $N$ Engl J Med 383;16, April 24, 2020, pp. 1-9, pp. 2 s.

25 World Health Organization (WHO), Coronavirus disease 2019 (COVID-19). Situation Report-51, 11 March 2020, https://www.who.int/ docs/default-source/coronaviruse/situation-reports/20200311-sitrep51-covid-19.pdf?sfvrsn=1ba62e57_10 (consultado en: 10/05/2020).

26 GANDHI, R./LYNCH, J./DEL RIO, C., "Mild or Moderate Covid-19", en $N$ Engl J Med 383;16, April 24, 2020, pp. 1-9, pp. 4 ss. 
y mayo. La sintomatología también es muy semejante, y la enfermedad que puede llegar a causar, una neumonía atípica. Los mecanismos para detectarlo también son coincidentes, test PCR, siglas que corresponden en inglés a polymerasechain-reaction, cuya traducción sería reacción en cadena de la polimerasa ${ }^{27}$. También se asemeja por la forma de transmisión, al menos por las vías de transmisión. Y en cuanto a las medidas de control para evitar la propagación, también coinciden, al ser en realidad medidas epidemiológicas clásicas de contención de enfermedades contagiosas. Pero entre ambos virus existen ciertas diferencias, algunas de ellas de especial relevancia. Mientras que en el SARS-CoV-1 los niños no desempeñaban un papel importante en la transmisión del virus, esto parece ser completamente diferente en el caso del SARS-CoV-2. Pero la principal diferencia es que mientras el primero se transmite sólo por personas con sintomatología, es decir, cuando ya se ha manifestado la enfermedad, el segundo se puede transmitir por personas que no presentan sintomatología. Así, la transmisión por asintomáticos constituye el talón de Aquiles en las estrategias de control de la COVID-1928. Las medidas tradicionales como el control de temperatura, la cuarentena de personas con síntomas, el aislamiento de sus contactos, etc., ayudan a reducir la expansión del virus, pero el gran problema y lo que exige extremar las medidas de higiene, de distanciamiento social, de uso de mascarillas, es que el virus se transmite por personas que en apariencia no están contagiadas. En esa línea, los test PCR constituyen un medio adecuado para identificar incluso entre

27 PEIRIS/YUEN, K.Y./OSTERHAUS, A./STÖHR. K., "The severe acute respiratory sindrome", en $N$ Engl J Med 349;25, December 18, 2003, pp. 2431-41, p. 2436; GANDHI, R./LYNCH, J./DEL RIO, C., "Mild or Moderate Covid-19”, en N Engl J Med 383;16, April 24, 2020, pp. 1-9, pp. 2.

28 GANDHI, M./YOKOE, D./HAVLIR, D.V., "Asymptomatic transmission, the Achilles' heel of current strategies to control Covid-19", en $N$ Eng J Med, April 27, 2020, pp. 1-3, p. 2. 
la población sin sintomatología personas infectadas, adoptando a continuación las medidas de aislamiento necesarias. En todo caso, este hecho explica, en parte, cómo se produjo la expansión global del virus.

Excurso: sobre recientes experiencias pasadas y potenciales peligros futuros

En muchas ocasiones se ha repetido que este nuevo virus se presentó y se desarrolló de forma inesperada, de tal manera que tomó a todos desprevenidos, incluyendo a organismos internacionales, gobiernos, autoridades y ciudadanía en general. Sin embargo, una aproximación a la literatura científica sobre el SARS-CoV-1 (el virus identificado en el año 2002), es decir, publicaciones en revistas o editoriales de reconocido prestigio, derivadas por tanto de estudios académicos, contrastados y divulgados en congresos científicos, nos puede llevar, como mínimo, a dudar de aquella afirmación y de la validez y operatividad del sistema global y estatal de alarma existente en materia de salud pública y, podríamos decir, de seguridad en general. Porque en realidad, lo acontecido en relación con el SARS-CoV-2 (el virus identificado en 2019) fue experimentado ya en tiempos muy recientes, en los años 2002 y 2003, y todo el análisis científico de entonces quedó perfectamente documentado. Tanto es así que prácticamente todos los episodios vividos a partir del brote del virus en 2019 son idénticos a lo sucedido a partir del brote en el año 2002. En este sentido, ABRAHAM señala que "el SARS martilleó nuestro hogar con el mensaje de que una enfermedad infecciosa, incluso aunque no sea usada como un arma, podría ser tan perturbadora y costosa como una guerra convencional. Y a diferencia de una guerra convencional, no había una alarma prioritaria de una guerra microbiana. Irrumpió sin advertencia alguna, y las sociedades no estaban preparadas para enfrentarla. El director de la red de hospitales públicos de Hong Kong, el Doctor William Ho, describió el SARS como 'el ataque a Pearl Harbour magnificado y con un patrón de rápido escalamiento. Al principio, nada sabíamos 
del enemigo'. La analogía con la guerra resuena a lo largo de la crisis del SARS" ${ }^{29}$. Estas reflexiones se replicaron durante la presente crisis, hasta el punto de que el propio presidente de los EE.UU. llegó a comparar la expansión del SARSCoV-2 en suelo norteamericano con, precisamente, el ataque a Pearl Harbour ${ }^{30}$, reproduciendo casi literalmente la frase que había sido dicha hacía apenas diecisiete años antes. Pero las advertencias quedaron reflejadas por escrito todavía con más precisión. Así, ya entonces se constató que "esta guerra se dirigió a la infraestructura vital de la sociedad, en este caso, el sistema público de salud. El virus golpeó primero a personal médico, de enfermería, y trabajadores de servicios sanitarios, acribillándolos como a soldados en el campo de batalla. Pero a diferencia de los soldados, que están entrenados para hacer frente a la muerte, los trabajadores sanitarios están entrenados para salvar vidas. Sin advertirlo, se encontraron en primera línea de batalla donde eran carne de cañón. Y como en una guerra de guerrilla, el virus del SARS volvió los sistemas públicos de salud en su propia ventaja: expandiéndose en hospitales y encontrando nuevas víctimas que llevaban la enfermedad a lo largo y ancho de la comunidad. No sólo era esta una enfermedad para la cual la medicina moderna no tenía cura, era una enfermedad que usaba las instituciones de la medicina moderna para extenderse" ${ }^{31}$.

La población occidental no tuvo un conocimiento exacto de la magnitud de la tragedia provocada por el SARSCoV-1 porque, a diferencia de la actual, no llegó a provocar contagios, muertes, y efectos colaterales en Europa y América, pero "el coste económico de la enfermedad fue también devastador. En un pequeño espacio de tiempo de alrededor

29 ABRAHAM, T., Twenty-first century plague. The story of SARS, Hong Kong, 2004, p. 2.

30 Véase, https://www.bbc.com/news/world-us-canada-52568405 (consultado en: 11/05/2020).

31 ABRAHAM, T., Twenty-first century plague. The story of SARS, Hong Kong, 2004, p. 2. 
de tres meses, el SARS alcanzó todos los continentes y paralizó algunas de las ciudades y regiones más dinámicas del mundo. La economía global perdió alrededor de 30 billones de dólares americanos en producción, la mayoría en Asia. Los gobiernos tomaron medidas como cuarentenas y otras restricciones para los viajeros, revirtiendo una tendencia global que había durado décadas de eliminación de restricciones para los viajes. Los aeropuertos se vaciaron, las aerolíneas cancelaron los vuelos y pareció como si el virus hubiese bloqueado las arterias de un mundo del siglo XXI, interconectado y globalizado"32. A partir de ahí, "cuando la epidemia se redujo, el virus causante de la enfermedad había sido identificado, se había llegado a un amplio consenso sobre su método de transmisión y se había acumulado un significativo conocimiento clínico sobre la mejor forma de tratar la enfermedad. Pero había también muchas preguntas sin responder, ¿cómo era posible que a principios del siglo XXI, con la batería de recursos de la medicina moderna a disposición, el género humano fuese todavía tan vulnerable a una enfermedad causada por un microbio? ¿Si esta enfermedad había irrumpido sin aviso y tendiendo una emboscada al mundo con efectos tan devastadores había otras nuevas enfermedades esperando para atacar de una forma similar? ¿Estábamos ante un siglo de nuevas enfermedades?" 33 . En este mismo sentido, en un trabajo de WEBER et al. se señalaba que "la respuesta al brote en 2002-03 del SARS, a pesar de efectivo fue precedida de una confusión inicial sobre la identidad del patógeno causante, la incerteza sobre la epidemiología de la transmisión y de la expansión, y las dificultades respecto a la fluidez de la información debido a las rivalidades políticas" ${ }^{\prime 34}$. Dando un

32 ABRAHAM, T., Twenty-first century plague. The story of SARS, Hong Kong, 2004, p. 3.

33 ABRAHAM, T., Twenty-first century plague. The story of SARS, Hong Kong, 2004, p. 4.

34 WEBER, S.G./BOTTEI, Ed./COOK, R./O'CONNOR, M., "SARS, emerging infections, and bioterrorism preparedness", The Lancet, Infectious Diseases Vol. 4 August 2004, pp. 482-484, p. 482. 
paso más allá, estos autores ofrecían una lectura de lo sucedido que tenía como finalidad llamar la atención sobre el enorme riesgo que estas enfermedades suponen para el ser humano, pues "ofrecen lecciones muy valiosas para prepararse ante un ataque deliberado con agentes biológicos practicado por terroristas (...). Donde los sanitarios y los responsables políticos ven enfermedades como el SARS desde el punto de vista de los tratamientos de salud pública, los terroristas podrían verlas como una oportunidad para utilizarlas como $\operatorname{armas}{ }^{35}$. Las razones que ofrecen para sostener esta postura son no sólo interesantes a efectos de defender su hipótesis, sino también con carácter general, independientemente de que una enfermedad de estas características sea utilizada como arma biológica o haya surgido espontánea y naturalmente. Así, "el patógeno del SARS es altamente contagioso. De los trabajadores del sistema de salud que se expusieron sin protección a los casos iniciales de SARS en Asia, más del $50 \%$ cayó enfermo. (...) La letalidad también hace al coronavirus del SARS viable como agente de bioterrorismo. (...) El factor de mayor preocupación sobre la potencialidad del coronavirus del SARS como arma biológica es quizá la dificultad para poder detectar el ataque. (...) Así, un ataque coincidente con la temporada de la gripe puede no ser detectado hasta que la rápida transmisión ya haya tenido lugar"36.

\section{3. ¿El riesgo de contagio del SARS-COV-2 y el desarrollo de COVID-19 pueden considerarse riesgos laborales?}

La Ley 31/1995, de 8 de noviembre, de prevención de riesgos laborales (en adelante LPRL), que constituye el

35 WEBER, S.G./BOTTEI, Ed./COOK, R./O'CONNOR, M., "SARS, emerging infections, and bioterrorism preparedness", The Lancet, Infectious Diseases Vol. 4 August 2004, pp. 482-484, p. 482.

36 WEBER, S.G./BOTTEI, Ed./COOK, R./O'CONNOR, M., "SARS, emerging infections, and bioterrorism preparedness", The Lancet, Infectious Diseases Vol. 4 August 2004, pp. 482-484, p. 483. 
Derecho necesario mínimo indisponible y, por lo tanto, la norma de referencia en esta materia, proporciona una definición auténtica de riesgo laboral. Define el riesgo laboral como "la posibilidad de que un trabajador sufra un determinado daño derivado del trabajo" ${ }^{37}$. A continuación, establece que "se considerarán daños derivados del trabajo las enfermedades, patologías o lesiones sufridas con motivo u ocasión del trabajo"38. Por su parte, en el art. 1 dispone que "la presente Ley tiene por objeto promover la seguridad y la salud de los trabajadores mediante la aplicación de medidas y el desarrollo de las actividades necesarias para la prevención de riesgos derivados del trabajo".

Atendiendo a estos preceptos se podría considerar que el riesgo laboral es aquel cuya etiología está directamente vinculada con el desempeño de un trabajo determinado, es decir, que el origen primigenio del riesgo está en la propia actividad laboral. Desde esta interpretación restrictiva de "riesgo laboral" cabría discutir si la COVID-19 se puede considerar un riesgo laboral o, por lo menos, si puede tener esa consideración sólo en muy concretos sectores de actividad (p. ej. en el sanitario) o, por el contrario, alcanza a todos los sectores de actividad.

Esta discusión se puede ver alimentada por el art. 5 RDL 6/2020, de 10 de marzo, por el que se adoptan determinadas medidas urgentes en el ámbito económico para la protección de la salud pública, que dispone en su apartado primero, "al objeto de proteger la salud pública, se considerará, con carácter excepcional, situación asimilada a accidente de trabajo, exclusivamente para la prestación económica de incapacidad temporal del sistema de Seguridad Social, aquellos periodos de aislamiento o contagio de las personas trabajadoras provocados por el virus COVID-19”. De esta

37 Art. 4 Ley 31/1995, de 8 de noviembre, de prevención de riesgos laborales.

38 Art. 4 Ley 31/1995, de 8 de noviembre, de prevención de riesgos laborales. 
disposición normativa resultan criticables, desde mi punto de vista, al menos dos cuestiones. El legislador comete una imprecisión terminológica al referirse al "virus COVID-19". Como ya se ha explicado más arriba, el término COVID-19 es el acrónimo de la expresión inglesa Coronavirus disease 19 cuya traducción en español sería "enfermedad de coronavirus 19". El virus que provoca la "enfermedad COVID-19" (expresión que resulta, en cierto modo, redundante) es el SARS-CoV-2. Así que el legislador debería substituir el término "COVID-19" por el término "SARS-CoV-2" para mantener el sentido de la frase. O podría cambiar el término "virus" por el de "enfermedad". Por otra parte, resulta cuando menos confusa la frase "aquellos períodos de aislamiento o contagio de las personas trabajadoras provocado por el virus COVID-19". Tal y como se redacta podría entenderse que se equipara semánticamente el período de aislamiento de las personas trabajadoras con el período de contagio de las personas trabajadoras. La primera de las expresiones no ofrece problemas interpretativos. Se trata de aquel intervalo temporal en que la persona trabajadora debe permanecer "aislada" o en cuarentena, bien por manifestar sintomatología compatible con la enfermedad de COVID-19, aunque no requiera una baja por enfermedad, bien por tratarse de una persona que tenga la enfermedad (confirmada a través de PCR), nuevamente aunque no requiera baja por enfermedad, bien por haber mantenido contacto estrecho con una persona sospechosa de haber contraído la enfermedad o confirmada, bien por pertenecer a un grupo de riesgo o por otra causa asimilable. Sin embargo no resulta comprensible a qué se refiere la segunda expresión, el período de contagio. De hecho, en el apartado segundo del mismo artículo se dice que "en ambos casos la duración de esta prestación excepcional vendrá determinada por el parte de baja por aislamiento y la correspondiente alta", es decir, no se habla del "parte de baja por contagio". Podría considerarse que los dos sintagmas yuxtapuestos son, "periodos de aislamiento" y "contagio 
de las personas trabajadoras provocado por el COVID-19", sin entender la elipsis del segmento sintáctico "periodo". Sin embargo, este segundo elemento no parece añadir nada pues se puede considerar como una de las causas de baja por aislamiento. Tanto es así que hasta en el apartado segundo, como acabamos de ver, quedan asimilados. Es cierto que la determinación de la fecha del contagio puede ser tenida en cuenta como fecha del hecho causante y, por lo tanto, se podría justificar esa referencia explícita. Esto es lo que parece querer decir el legislador cuando en el apartado cuarto dispone, "la fecha del hecho causante será la fecha en que se acuerde el aislamiento o enfermedad del trabajador, sin perjuicio de que el parte de baja se expida con posterioridad a esa fecha". Sin embargo, como vemos, aquí se habla de "enfermedad" y no de "contagio", aumentando así la confusión. En todo caso, lo que nos interesa al objeto de este trabajo es que la concreción del riesgo de que la persona trabajadora contraiga $\mathrm{CO}$ VID-19 en una baja por aislamiento, se asimila a accidente de trabajo, pero sólo a efectos de prestación económica por parte de la Seguridad Social. Por tanto, la enfermedad de COVID-19 no tendría la consideración de accidente de trabajo y, mucho menos, de enfermedad profesional ${ }^{39}$.

Sin embargo, son varias las razones que deben llevarnos a concluir que el riesgo de infección del SARS-CoV-2 es un riesgo abarcado por las normas de prevención de riesgos laborales.

En primer lugar, porque el daño que del mismo puede traer causa lo es con motivo u ocasión del trabajo, tal y como se establece en la propia Ley 31/1995, de 8 de noviembre. Esto, en mi opinión, no ofrece duda alguna a la vista de la enfermedad y sus características, así como su irrupción repentina. Además, en muchas actividades profesionales el propio desempeño laboral, por la naturaleza de la profesión,

39 De hecho, esta es una reivindicación sindical, como se puede ver en "UGT pide que el contagio por Covid de sanitarios sea considerado como enfermedad profesional", Diario La Ley, 6 de mayo de 2020. 
implica ese riesgo de contagio. Así, en las actividades sanitarias, con una exposición como tantas veces se ha dicho "en primera línea", al tener que tratar con pacientes contagiados y tener que llevar intervenciones de alto riesgo para su propia salud como son intubaciones, extubaciones, entre otras muchas. Es más, en relación con estas actividades la norma específica que debería ser de aplicación es el RD 664/1997, de 12 de mayo, sobre la protección de los trabajadores contra los riesgos relacionados con la exposición a agentes biológicos durante el trabajo que, según dispone en su art. 1.1, tiene por objeto "la protección de los trabajadores contra los riesgos para su salud y su seguridad derivados de la exposición a agentes biológicos durante el trabajo, así como la prevención de dichos riesgos". A estos efectos, el art. 2 de esta norma entiende por agente biológico cualquier microorganismo, es decir, toda entidad microbiológica, celular o no, capaz de reproducirse o de transferir material genético. A continuación, en el art. 3 se establece una clasificación de los agentes biológicos en función del riesgo de infección, distinguiendo cuatro grupos $^{40}$. En el anexo 2 del RD 664/1997, de 12 de mayo, se contiene un listado de agentes biológicos con su clasificación de acuerdo con el art. 3 antes referido. Entre estos agentes

40 Art. 3 RD 664/1997, de 12 de mayo, dispone: "1. A efectos de los dispuesto en el presente Real Decreto, los agentes biológicos se clasifican, en función del riesgo de infección, en cuatro grupos: a) Agente biológico del grupo 1: aquél que resulta poco probable que cause una enfermedad en el hombre. b) Agente biológico del grupo 2: aquél que puede causar una enfermedad en el hombre y puede suponer un peligro para los trabajadores, siendo poco probable que se propague a la colectividad y existiendo generalmente profilaxis o tratamiento eficaz. c) Agente biológico del grupo 3: aquél que puede causar una enfermedad en el hombre y puede suponer un peligro para los trabajadores, siendo poco probable que se propague a la colectividad y existiendo generalmente profilaxis o tratamiento eficaz. d) Agente biológico del grupo 4: aquél que causando una enfermedad grave en el hombre supone un serio peligro para los trabajadores, con muchas probabilidades de que se propague a la colectividad y sin que exista generalmente una profilaxis o un tratamiento eficaz". 
biológicos nos encontramos con los coronaviridae, es decir, la familia de coronavirus, clasificados en el grupo 2, esto es, que pueden causar una enfermedad en las personas y puede suponer un peligro para los trabajadores, siendo poco probable que se propague a la colectividad y existiendo generalmente profilaxis o tratamiento eficaz. Aunque hay que decir que a la vista del comportamiento de este nuevo coronavirus, el SARS-CoV-2 debería tener otra clasificación ${ }^{41}$. Pero también se deberían incluir aquí todas aquellas profesiones que impliquen atención al público con interacción y con la presencia de un grupo de personas, como podrían serlo, por ejemplo, las profesiones vinculadas a la enseñanza en cualquiera de sus niveles (primaria, secundaria y universitaria), muchísimas de las vinculadas al sector servicios (hostelería y restauración, hotelería, servicios aeroportuarios, etc.), entre otras.

En segundo lugar, porque las normas de prevención de riesgos laborales tanto de Derecho duro como de Derecho blando dictadas por los Poderes públicos para hacer frente a la enfermedad de COVID-19 ponen de manifiesto que el contagio es un riesgo laboral que debe ser objeto de prevención.

El documento de referencia en esta materia es el "Procedimiento de actuación para los servicios de prevención de riesgos laborales frente a la exposición al SARS-CoV-2", publicado por el Ministerio de Sanidad por primera vez el día 28 de febrero de 2020, siendo objeto de sucesivas revisiones y actualizaciones desde entonces hasta llegar a la versión actualmente en vigor, de 30 de abril de $2020^{42}$. Este documento,

41 En este sentido, SALVADOR, N./PEÑAlOSA, C., "Responsabilidad empresarial por contagio", Diario La Ley, N. ${ }^{\circ}$ 9631, 2020, pp. 1-6, p. 1, señalan "el COVID-19 se encuadra en el nivel más alto de gravedad (agente biológico grupo 4) puesto que, causando una enfermedad grave en el hombre, supone un serio peligro para los trabajadores, con muchas probabilidades de que se propague a la colectividad y sin que exista generalmente una profilaxis o un tratamiento eficaz".

42 Véase en https://www.mscbs.gob.es/profesionales/saludPublica/ccayes/alertasActual/nCov-China/documentos.htm (consultado en 19/05/2020). Sobre 
en cuya redacción ha participado el Ministerio de Trabajo y Economía Social establece que "corresponde a las empresas evaluar el riesgo de exposición en que se pueden encontrar las personas trabajadoras en cada una de las tareas diferenciadas que realizan y seguir las recomendaciones que sobre el particular emita el servicio de prevención, siguiendo las pautas y recomendaciones formuladas por las autoridades sanitarias" ${ }^{43}$. A continuación, en función de la naturaleza de las actividades profesionales y de los mecanismos de transmisión del SARS-CoV-2, se establecen los escenarios de exposición en los que se pueden encontrar los trabajadores, clasificándolos en tres niveles de riesgo. El primer nivel es el de "exposición de riesgo", identificándose como tal todas aquellas situaciones laborales en las que se puede producir un contacto estrecho con un caso posible, probable o confirmado de infección por el virus, sintomático. El segundo nivel es el de "exposición de bajo riesgo", aquellas situaciones laborales en las que la relación que se pueda tener con un caso posible, probable o confirmado, no incluye contacto estrecho. Finalmente, el tercer nivel es el de "baja probabilidad de exposición", en el que se encontrarían trabajadores que no tienen atención directa al público o, si la tienen, se produce a más de dos metros de distancia, o disponen de medidas de protección colectiva que evitan el contacto. Esta clasificación de los tres niveles de exposición al riesgo tiene como objetivo permitir que cada empresa tome decisiones sobre las medidas preventivas a adoptar basándose en la información recabada mediante la evaluación de riesgo de exposición específica, es decir, adaptando la clasificación referida a la

este documento, véase, BLASCO PELLICER, A./LÓPEZ BALAGUER, M./ALEGRE BUENO, M./RAMOS MORAGUES, F./TALÉNS VISCONTI, E., Análisis normativo de las medidas laborales y de Seguridad Social frente a la crisis del COVID-19, Valencia, 2020, pp. 22 ss.

43 Ministerio de Sanidad, "Procedimiento de actuación para los servicios de prevención de riesgos laborales frente a la exposición al SARSCoV-2", 2020, p. 3. 
concreta actividad. En el tercer bloque del documento, bajo la rúbrica de "medidas de prevención", se recogen las medidas de carácter organizativo, de protección personal (no sólo de equipos de protección individual -EPI-), las relativas a trabajadores especialmente sensibles en relación con la infección de SARS-CoV-2 atendiendo al estado de conocimientos de la ciencia médica, cuestiones relativas al estudio y manejo de contactos, así como el protocolo de actuación en relación con el aislamiento temporal de trabajadores.

Este documento está directamente complementado con la "Nota interpretativa de los escenarios de riesgo de exposición establecidos en el procedimiento de actuación para los servicios de prevención de riesgos laborales frente a la exposición al nuevo coronavirus (SARS-CoV-2)", publicado por el Ministerio de Sanidad ${ }^{44}$. Este documento, como el propio título indica, establece unas pautas interpretativas para aclarar parte del contenido del documento anterior. Así, advierte que en relación con la clasificación de los riesgos el Ministerio ofrece algunos ejemplos de personas trabajadoras que cumplen con las definiciones para ser ubicadas en cada escenario de riesgo y los requerimientos relativos a los equipos de protección, pero esa referencia tiene una mera finalidad ejemplificativa, no constituye ni una relación exhaustiva ni tampoco un sistema de numerus clausus. En este mismo sentido, esta nota aclara que los requerimientos de protección personal que se citan estarán en función de la evaluación específica del riesgo de exposición de cada caso. Esta evaluación es la única actividad técnica que podrá servir de base para tomar las decisiones técnico-preventivas adaptadas a cada caso. También se pronuncia sobre cómo ha de entenderse el escenario que requiere el uso de EPI y

44 Véase,

https://www.mscbs.gob.es/profesionales/saludPublica/ccayes/alertasActual/nCov-China/documentos/NOTA_INTERPRETATIVA_TABLA_1_PROCEDIMIENTO_SPRL.pdf (consultado en 19/05/2020). 
finalmente señala que "el procedimiento ofrece, además, un conjunto de medidas preventivas de carácter organizativo para minimizar el contacto entre las personas trabajadoras y entre estas últimas y otras personas que puedan concurrir en su lugar de trabajo o actividad laboral. En este sentido, la disposición de los puestos de trabajo, la organización de la circulación de personas y la distribución de espacios (mobiliario, estanterías, pasillo, etc.), los mecanismos de control de acceso en las entradas de los locales, etc., son medidas descritas en el Procedimiento que pueden servir de orientación" 45 . Complementando a los anteriores se debe tener en cuenta el documento "Instrucciones sobre la realización de pruebas diagnósticas para la detección del COVID-19 en el ámbito de las empresas" (sic), publicado por el Ministerio de Sanidad y actualizado en sucesivas ocasiones ${ }^{46}$. En el citado documento se establece que "en el escenario actual, la intervención de los servicios de prevención frente a la exposición al SARS$\mathrm{CoV}-2$, en el ámbito de las empresas es crucial, adaptando su actividad con recomendaciones actualizadas y de cumplimiento de las medidas de prevención" ${ }^{47}$. Y continúa diciendo, "a día de hoy, los servicios de prevención de riesgos laborales que realizan actividades sanitarias deben limitar la realización de pruebas diagnósticas para la detección de la COVID-19 a los ámbitos de actuación descritos, establecidos por el Ministerio de Sanidad, y están llamados a colaborar con las autoridades sanitarias en la detección precoz de

45 Véase, Ministerio de Sanidad, "Nota Interpretativa de los escenarios de riesgo de exposición establecidos en el procedimiento de actuación para los servicios de prevención de riesgos laborales frente a la exposición al nuevo coronavirus (SARS-COV-2)", s.d., p. 2.

46 Véase, https://www.mscbs.gob.es/profesionales/saludPublica/ccayes/alertasActual/nCov-China/documentos/instruccionesPruebasDiagnosticasEmpresas.pdf (consultado en 19/05/2020).

47 Véase, Ministerio de Sanidad, "Instrucciones sobre la realización de pruebas diagnósticas para la detección del COVID-19 en el ámbito de las empresas, 2020, p. 3. 
todos los casos compatibles con COVID-19 para controlar la transmisión" 48 .

Por su parte, el Ministerio de Trabajo y Economía Social publicó la "Guía para la actuación en el ámbito laboral en relación al nuevo coronavirus" ${ }^{49}$. Este documento, además de contener una explicación sobre el art. 21 LPRL, relativo a la paralización de la actividad laboral en caso de riesgo grave e inminente, a lo que me referiré más adelante, establece, redundando en el contenido de documentos anteriores, que "las empresas deberán adoptar aquellas medidas preventivas de carácter colectivo o individual que sean indicadas, en su caso, por el servicio de prevención de acuerdo con la evaluación de riesgos, esto es, en función del tipo de actividad, distribución y características concretas de la actividad que la empresa realice" ${ }^{50}$. A partir de aquí, son numerosas las normas de prevención de riesgos laborales derivados del virus SARS-CoV-2 que se han ido dictando y publicando. Así, sin ánimo de exhaustividad pero tratando de recoger algunas de las más significativas, se pueden destacar las siguientes. La "Instrucción de la Secretaría General de Función Pública sobre medidas y líneas de actuación en materia de prevención de riesgos laborales frente al COVID-19 de cara a la reincorporación presencial del personal" (sic) ${ }^{51}$, que tiene por objeto

48 Véase, Ministerio de Sanidad, "Instrucciones sobre la realización de pruebas diagnósticas para la detección del COVID-19 en el ámbito de las empresas, 2020, p. 3.

49 Véase, http://www.mitramiss.gob.es/ficheros/ministerio/inicio_destacados/Gua_Definitiva.pdf (consultado en 19/05/2020). Sobre este documento, véase, BLASCO PELLICER, A./LÓPEZ BALAGUER, M./ ALEGRE BUENO, M./RAMOS MORAGUES, F./TALÉNS VISCONTI, E., Análisis normativo de las medidas laborales y de Seguridad Social frente a la crisis del COVID-19, Valencia, 2020, pp. 21 ss.

50 Ministerio de Trabajo y Economía Social, "Guía para la actuación en el ámbito laboral en relación al nuevo coronavirus", s.d., p. 4.

51 Ministerio de Política Territorial y Función Pública, "Instrucción de la Secretaría General de Función Pública sobre medidas y líneas de actuación en materia de prevención de riesgos laborales frente al COVID-19 de cara a la reincorporación presencial del personal", 2020. 
servir de marco general en los departamentos y organismos públicos de la Administración General del Estado a la hora de establecer medidas preventivas para garantizar la seguridad de los empleados públicos, para proteger su salud y evitar contagios en un escenario de reincorporación del personal de la Administración a sus puestos de trabajo de manera presencial. Entre las medidas preventivas que se deben adoptar podemos ver una excepción de reincorporación en una primera etapa de aquellas personas consideradas especialmente vulnerables por sufrir una determinada patología previa, por razón de edad (establece el umbral en los 60 años) y mujeres embarazadas. También contempla la flexibilización horaria, tanto de entrada como de salida, para evitar aglomeraciones en horas punta, y establecimiento de turnos. En todo caso, señala que estas circunstancias estarán en paralelo al mantenimiento de la posibilidad de trabajo en modalidades no presenciales, como el teletrabajo. En relación con el centro de trabajo, establece la obligatoriedad de adoptar medidas para asegurar el distanciamiento interpersonal de dos metros, la disponibilidad de agua, jabón, toallas de papel desechables y soluciones hidroalcohólicas (dispensadores), extremar la limpieza especialmente en las zonas comunes, la ventilación y poner atención a la gestión de residuos. Indica que se habilitará un sentido de entrada y otro de salida en el acceso al centro de trabajo, limitando el aforo de los comedores o zonas similares, y de los ascensores. Hace una mención particular de las funciones de los servicios de prevención de riesgos laborales y de la necesidad de mantener informados y formados en relación con todas estas medidas a los trabajadores del centro.

La Orden JUS/394/2020, de 8 de mayo, por la que se aprueba el Esquema de Seguridad Laboral y el Plan de Desescalada para la Administración de Justicia ante el COVID-19 (sic), contiene de forma detallada todas las medidas preventivas que en esta materia deben adoptarse en los centros de trabajo de la Administración de Justica. Se contemplan 
medidas de protección colectiva, de organización del trabajo, de protección individual destinadas todas ellas a minimizar el riesgo de contagio del virus que provoca la enfermedad de COVID-19. La medida nuclear sobre la que se hace pivotar esta norma es la medida de distancia social, procurando establecer distancias mínimas de seguridad de aproximadamente dos metros en todos los espacios de trabajo. En la atención al público se prima prácticamente con carácter absoluto la atención por vía telefónica o a través de correo electrónico, siendo muy excepcional y sujeta a autorización previa la posibilidad de acudir personalmente a la sede judicial. En este mismo sentido, se señala que "se optimizará la utilización de los medios telemáticos disponibles con el objetivo de evitar desplazamientos físicos especialmente si el centro de trabajo no cuenta con espacios donde los trabajadores puedan respetar la distancia interpersonal" 52 . Una exposición de la normativa sobre prevención de riesgos laborales en los diferentes sectores de actividad se puede encontrar en el documento "Prevención de riesgos laborales vs. COVID-19-Compendio no exhaustivo de fuentes de información-", del INSST, publicado en su primera versión el 25 de marzo de 2020 con sucesivas actualizaciones posteriores ${ }^{53}$.

En tercer lugar, porque el riesgo de contagio por SARS-CoV-2 se ha interpretado como una causa para aplicar el art. 21 LPRL. Así lo ha considerado expresamente el Ministerio de Trabajo y Economía Social a través de la "Guía para la actuación en el ámbito laboral en relación al nuevo

52 Véase Orden JUS/394/2020, de 8 de mayo, por la que se aprueba el Esquema de Seguridad Laboral y el Plan de Desescalada para la Administración de Justicia ante el COVID-19", Anexo I, apartado 7.1.

53 Véase https://www.insst.es/documents/94886/693030/Prevenci $\%$ C3\%B3n+de+ riesgos+laborales+vs.+COVID-19+-+Compendio+no+exhaustivo+de +fuentes+de+informaci $\% \mathrm{C} 3 \% \mathrm{~B} 3 \mathrm{n} / 4098124 \mathrm{f}-5324-43 \mathrm{a} 6-8881-0 \mathrm{bbd} 4 \mathrm{e}-$ 358 de7 (consultado en 22/05/2020). 
coronavirus" ${ }^{54}$. El citado art. 21 LPRL dispone: "1. Cuando los trabajadores estén o puedan estar expuestos a un riesgo grave e inminente con ocasión de su trabajo, el empresario estará obligado a: a) Informar lo antes posible a todos los trabajadores afectados acerca de la existencia de dicho riesgo y de las medidas adoptadas o que, en su caso, deban adoptarse en materia de protección. b) Adoptar las medidas y dar las instrucciones necesarias para que, en caso de peligro grave, inminente e inevitable, los trabajadores puedan interrumpir su actividad y, si fuera necesario, abandonar de inmediato el lugar de trabajo. En este supuesto no podrá exigirse a los trabajadores que reanuden su actividad mientras persista el peligro, salvo excepción debidamente justificada por razones de seguridad y determinada reglamentariamente. (...)". Pues bien, el reconocimiento de los riesgos derivados del SARSCoV-2 como riesgos laborales que deben ser objeto de protección es claro y expreso cuando el Ministerio de Trabajo y Economía social dispone que "en aplicación de esta norma [scil. art. 21.1 LPRL], las empresas deberán proceder a paralizar la actividad laboral en caso de que exista un riesgo de contagio por coronavirus en el centro de trabajo, ello no obstante la activación de medidas que permitan el desarrollo de la actividad laboral de forma alternativa o bien, de ser necesario, la adopción de medidas de suspensión temporal de la actividad (...)"55. Y continúa advirtiendo que "asimismo, por decisión mayoritaria, la representación unitaria o los delegados de prevención, podrán acordar la paralización de la actividad de las personas trabajadoras afectadas por el riesgo de contagio grave inminente por coronavirus" ${ }^{56}$.

54 Véase

http://www.mitramiss.gob.es/ficheros/ministerio/inicio_destacados/ Gua_Definitiva.pdf (consultado en 22/05/2020).

55 Ministerio de Trabajo y Economía Social, "Guía para la actuación en el ámbito laboral en relación al nuevo coronavirus", 2020, p. 2.

56 Ministerio de Trabajo y Economía Social, "Guía para la actuación en el ámbito laboral en relación al nuevo coronavirus”, 2020, p. 3. Conforme al art. 21.2 LPRL. 
Además de todo lo señalado anteriormente, se deben añadir aquí los pronunciamientos judiciales que ya se han producido sobre esta materia al menos en la jurisdicción del Orden de lo social. En este sentido cabe destacar por su precisión, extensión y contundencia argumentativa, la Sentencia del Juzgado de lo Social n. ${ }^{\circ} 1$ de Teruel, Sentencia 60/2020, de 3 de junio de 2020. La citada sentencia trae su causa en la demanda presentada por el Sindicato de profesionales sanitarios FASEMET frente al Servicio Aragonés de Salud (SAS), al Instituto aragonés de servicios sociales y frente a la Diputación general de Aragón. Las pretensiones de la demanda se concretan en que se declare que las Administraciones demandadas vulneraron los derechos de los trabajadores en materia de prevención de riesgos labores, al no proporcionarles los medios de prevención necesarios ante el SARS-CoV-2, el riesgo de contagio o infección y la posibilidad de desarrollar la enfermedad COVID-19, poniendo así en peligro la vida y la salud de aquéllos. A los efectos que aquí interesan, se indica que "no se ha cumplido por las empleadoras tal obligación ya que los EPIS proporcionados no han sido ni suficientes ni en otras ocasiones adecuados. A pesar de la existencia de importantes riesgos para la salud, integridad física e incluso para la vida, de los trabajadores, que se podrían haber minimizado con el uso de EPIS adecuados, la insuficiencia de los mismos ha impedido que quedara garantizada la seguridad y la salud de los trabajadores. (...) Los empleados y trabajadores sanitarios han estado desarrollando su trabajo, a pesar del grave e inminente riesgo para su vida y salud por su exposición al Covid-19, y ello, fundamentalmente, por la falta de medios de protección individuales adecuados, aun cuando podrían haber interrumpido y abandonado su actividad, pero gracias a su vocación de servicio a los demás, no sólo no han paralizado su trabajo, a pesar de las condiciones de protección precarias, sino que lo han desarrollado heroicamente (...). En definitiva, tanto la LPRL como el RD sobre EPIS, han sido infringidos por las demandadas al no proveerse a 
los trabajadores y empleados representados por el sindicato FASAMET, de los EPIS adecuados y suficientes para desempeñar su trabajo en condiciones de seguridad, sin riesgo para la seguridad o salud de los trabajadores. No consta limpieza de los EPIS que permitiera la reutilización de los mismos, ni se ha demostrado la sustitución periódica de éstos" ${ }^{57}$.

En conclusión, por todo lo dicho podemos afirmar que el virus del SARS-CoV-2 y los riesgos inherentes, en concreto, el riesgo de contraer la enfermedad de COVID-19, pueden ser considerados un riesgo laboral y, por lo tanto, deben entenderse abarcados por las normas de prevención de prevención de riesgos laborales.

\section{Responsabilidad penal por infracción de normas de pre- vención de riesgos laborales derivados del SARS-COV-2 y de la enfermedad de COVID-19.}

Una vez que hemos establecido que los riesgos vinculados al SARS-CoV-2 son riesgos laborales y, por tanto, susceptibles de ser abarcados por las normas de prevención de riesgos laborales, es hora de responder a la primera de las preguntas que nos planteamos en este trabajo ¿la infracción de normas de prevención de riesgos laborales derivados de la COVID-19 puede dar lugar a responsabilidad penal?

El art. $316 \mathrm{CP}$ señala como responsables a "los que con infracción de las normas de prevención de riesgos laborales y estando legalmente obligados, no faciliten los medios necesarios para que los trabajadores desempeñen su actividad con las medidas de seguridad e higiene adecuadas". A la vista de la literalidad de este precepto, la respuesta a la pregunta aquí planteada no admite dudas, es sí. La infracción de las normas de prevención de riesgos laborales, también de los específicos

57 Véase, Sentencia del Juzgado de lo Social n. ${ }^{\circ} 1$ de Teruel, Sentencia 60/2020, de 3 de junio de 2020, Fundamento de Derecho cuarto. 
derivados de la enfermedad COVID-19, y en especial, del virus que la causa, puede dar lugar a responsabilidad penal.

Este delito se configura como una norma penal en blanco pues el legislador penal se remite a normas extrapenales para terminar de integrar el tipo penal ${ }^{58}$. A partir de aquí, se discute a qué normas (de prevención de riesgos laborales) se refiere el legislador. Pues bien, en esta expresión cabe la totalidad de disposiciones normativas que regulan esta materia. Así, se debe incluir, desde luego, la LPRL, pues es la referencia en esta materia. Junto a ésta, las normas sectoriales, muchas de ellas con rango de reglamento. Se discute si también se incluyen los convenios colectivos ante la posible quiebra del principio de igualdad y de taxatividad, y con ello, de seguridad jurídica. Debemos inclinarnos por admitir los convenios colectivos como normas de prevención cuando entren a regular sobre esta materia ${ }^{59}$. En este sentido, el art. 2.2

58 Sobre esta cuestión polémica, véase DE VICENTE MARTÍNEZ, R., Derecho penal del trabajo. Los delitos contra los derechos de los trabajadores y contra la Seguridad Social, Valencia, 2020, pp. 500 ss.; SALVADOR, N./PEÑALOSA, C., "Responsabilidad empresarial por contagio", Diario La Ley, N. ${ }^{\circ} 9631,2020$, pp. 1-6, p. 3; MARTÍNEZ-BUJÁN PÉREZ, C., Derecho penal económico y de la empresa, Parte especial, $6 .{ }^{\text {a }}$ ed., Valencia, 2019, p. 921; NÚÑEZ CASTAÑO, E., "Delitos contra los derechos de los trabajadores", en GALÁN MUÑOZ, A./NÚÑEZ CASTAÑO, E., Manual de Derecho penal económico y de la empresa, 3. ${ }^{a}$ ed., Valencia, 2019, p. 304; MORALES HERNÁNDEZ, M. A., "Delitos contra los derechos de los trabajadores", en MARÍN DE ESPINOSA CEBALLOS, E. (dir.)/ESQUINAS VALVERDE, P. (coord.), Lecciones de Derecho penal. Parte especial, Valencia, 2018, p. 288. Sobre este delito, véase MARTÍNEZ-BUJÁN PÉREZ, C., "Delitos contra los derechos de los trabajadores. Delitos contra los derechos de los ciudadanos extranjeros", en GONZÁLEZ CUSSAC, J. L. (coord.), Derecho penal Parte Especial, 6. ${ }^{a}$ ed., Valencia, 2019, pp. 565 ss. MUÑOZ CONDE, F., Derecho penal, Parte especial, 22. ${ }^{\text {a }}$ ed., Valencia, 2019, p. 336.

59 En este mismo sentido, DE VICENTE MARTÍNEZ, R., Derecho penal del trabajo. Los delitos contra los derechos de los trabajadores y contra la Seguridad Social, Valencia, 2020, pp. 502 ss.; MARTÍNEZ-BUJÁN PÉREZ, C., Derecho penal económico y de la empresa, Parte especial, $6 .{ }^{\text {a }}$ ed., Valencia, 2019, p. 921. 
LPRL es claro, "las disposiciones de carácter laboral contenidas en esta Ley y en sus normas reglamentarias tendrán en todo caso el carácter de Derecho necesario mínimo indisponible, pudiendo ser mejoradas y desarrolladas en los convenios colectivos". Por tanto, los convenios colectivos pueden regular cuestiones en materia de prevención de riesgos, siempre que no lo hagan "a la baja", es decir, por debajo de los estándares de seguridad exigidos por la LPRL o por los reglamentos sectoriales. También puede ser discutido si junto a disposiciones legales, reglamentarias y los convenios colectivos, se deben incluir aquí otras normas que no alcanzan esos rangos normativos. Esto es, protocolos, guías de actuación, estándares, en muchos casos dictados desde organismos gubernamentales y otras desde entidades privadas pero con respaldo de los primeros. Esto es lo que podríamos llamar "soft law" en materia de prevención de riesgos laborales ${ }^{60}$. En mi opinión, la respuesta es afirmativa ${ }^{61}$. Todas estas disposiciones no dejan de ser "normas" dictadas con la pretensión de que por parte del destinatario se cumplan las medidas que en materia de prevención de riesgos es necesario adoptar en una determinada actividad laboral. Además, cuanto más específicas sean estas normas, más valor se le puede otorgar, puesto que tendrán en cuenta con más precisión y exactitud los concretos riesgos que para la salud y la vida de los trabajadores entraña una determinada actividad laboral y las respuestas preventivas serán más concretas y eficaces. Por tanto, todas

60 Sobre el discutible papel que puede jugar el "soft law", con especial referencia a las normas público-privadas y una crítica desde el punto de vista de los principios de legalidad y proporcionalidad, véase, RODRÍGUEZ VÁZQUEZ, V., "Democracia, sistemas de control y Derecho penal. Aproximación al fenómeno del soft law y de la externalización de los deberes estatales de control a través de los compliance programs", Revista Electrónica de Ciencia Penal y Criminología, núm. 22-11, 2020, pp. 8 ss.

61 En este mismo sentido, DE VICENTE MARTÍNEZ, R., Derecho penal del trabajo. Los delitos contra los derechos de los trabajadores y contra la Seguridad Social, Valencia, 2020, pp. 502 ss. 
las normas de prevención de riesgos laborales que se han dictado de forma célere en los últimos meses para determinar las medidas de seguridad que se deben adoptar en el trabajo para minimizar los riesgos derivados del SARS-CoV-2 tienen cabida en el precepto del art. 316 CP. A modo de ejemplo, se puede incluir aquí, la Orden JUS/394/2020, de 8 de mayo, por la que se aprueba el Esquema de Seguridad Laboral y el Plan de Desescalada para la Administración de Justicia ante el COVID-19 (sic), todas las disposiciones normativas sectoriales que se pueden ver en el documento "Prevención de riesgos laborales vs. Covid-19 -compendio no exhaustivo de fuentes de información-", publicado por el Ministerio de Trabajo y Economía Social, el día 25 de marzo de 2020 en su primera versión, el "Procedimiento de actuación para los servicios de prevención de riesgos laborales frente al SARSCoV-2", publicado por el Ministerio de Sanidad en su primera versión el 28 de febrero de 2020 y que desde entonces se ha convertido en el documento de referencia en la materia al que se remite cualquier otra disposición normativa.

En conclusión, la respuesta a la pregunta que justifica este epígrafe es sí. Sin lugar a dudas, la infracción de normas de prevención de riesgos laborales derivados del SARSCoV-2 puede dar lugar a responsabilidad penal conforme al art. $316 \mathrm{CP}$ o, en su caso, al art. $317 \mathrm{CP}$ en que se recoge la modalidad imprudente de aquel ${ }^{62}$.

Este delito parece configurarse como un delito de infracción de deber, aunque esta es una cuestión discutida. En este sentido, MARTÍNEZ-BUJÁN PÉREZ para quien, aunque resulta claro que exige un elemento de infracción de deber, queda por resolver la cuestión de si el injusto del art. 316 $\mathrm{CP}$ se agota exclusivamente en dicha infracción de deber o es un delito de naturaleza mixta, opción por la que se decide el

62 En este mismo sentido, SALVADOR, N./PEÑALOSA, C., "Responsabilidad empresarial por contagio", Diario La Ley, N. o 9631, 2020, pp. 1-6, p. 3 . 
autor y con la que yo estoy de acuerdo ${ }^{63}$. En consecuencia, conviene mencionar a continuación, aunque no nos podamos extender, aquellos elementos del tipo objetivo de injusto que deben concurrir junto con la citada infracción de las normas de prevención de riesgos laborales para que se realice el delito del art. $316 \mathrm{CP}$ o, en su caso, del art. $317 \mathrm{CP}$. Todo ello antes de tratar de responder a la segunda gran pregunta de este trabajo, quién puede ser responsable penalmente por infracción de las normas de prevención de riesgos laborales derivados del SARS-CoV-2.

Recordemos que el art. $316 \mathrm{CP}$ dispone, "los que con infracción de las normas de prevención de riesgos laborales y estando legalmente obligados, no faciliten los medios necesarios para que los trabajadores desempeñen su actividad con las medidas de seguridad e higiene adecuadas. De forma que pongan así en peligro grave su vida, salud o integridad física (...)". Por tanto, además de la infracción de riesgos laborales es necesario que concurra una determinada acción, como veremos, omisiva, y un concreto resultado, en este caso de peligro concreto. Para aproximarnos a cada uno de estos elementos, empezaré por identificar a qué "medios" se refiere el legislador, para a continuación delimitar qué se entiende por "no facilitar" dichos medios y terminar por señalar qué clase de resultado se requiere.

Respecto a la primera cuestión, parece pacífico que los medios a los que se refiere el tipo penal son los relativos a proteger la vida y salud de los trabajadores que desempeñan una determinada actividad. Sin embargo, se ha discutido tradicionalmente sobre el alcance del término "medios". Un sector doctrinal, minoritario, entiende que el término "medios" se refiere exclusivamente a los materiales, excluyéndose así los inmateriales, es decir, la formación, información y organización de los trabajadores ${ }^{64}$. Otro sector doctrinal,

63 MARTÍNEZ-BUJÁN PÉREZ, C., Derecho penal económico y de la empresa, Parte especial, 6. ${ }^{\mathrm{a}}$ ed., Valencia, 2019, p. 918.

64 ARROYO ZAPATERO, L., La protección penal de la seguridad en el trabajo, Madrid, 1981, pág. 142; el mismo, Manual de Derecho Penal del 
mayoritario, opta por hacer una interpretación extensiva del término, incluyendo tanto los medios materiales como los inmateriales ${ }^{65}$. Así, junto a los equipos individuales y

Trabajo, Barcelona, Praxis, 1988, pág. 66; LASCURAIN SÁNCHEZ, J.A., La protección penal de la seguridad e higiene, Madrid, 1994, pág. 330; el mismo, "La prevención penal de los riesgos laborales: cinco preguntas”, en CARBONELL MATEU, J.C./DEL ROSAL BLASCO, B./ MORILLAS CUEVA, L./ORTS BERENGUER, E./QUINTANAR DÍEZ, M. (coords.), Estudios Penales en Homenaje al profesor Cobo del Rosal, Madrid, 2005, pág. 584; el mismo, "La imputación penal del accidente de trabajo", en AA.VV, Tutela penal de la seguridad en el trabajo, Cuaderno penales José María Lidón, Bilbao, 2006, págs. 44 ss. (este autor parece cambiar de postura en las obras más recientes).

65 DE VICENTE MARTÍNEZ, R., Seguridad en el trabajo y Derecho penal, Barcelona, 2001, pág. 87; SERRANO-PIEDECASAS FERNÁNDEZ, J.R., "La responsabilidad penal del empresario, personal técnico y de los servicios de prevención en los delitos contra la seguridad e higiene en el trabajo", Revista Penal, 2002, n. ${ }^{\circ} 10$, pág. 100; CORCOY BIDASOLO, M./CARDENAL MONTRAVETA, S./HORTAL IBARRA, J.C., "Protección penal de los accidentes laborales", Revista del Poder Judicial, 2003, n. ${ }^{\circ} 71$, págs. 50 ss.; HORTAL IBARRA, J.C., "Legitimación y eficacia de la intervención penal en el ámbito de la prevención de riesgos laborales", en MIR PUIG, S./CORCOY BIDASOLO, M. (dirs.), GOMÉZ MARTÍN, V. (coord.), La Política Criminal en Europa, Barcelona, 2004, pág. 244; el mismo, Protección penal de la seguridad en el trabajo: una aproximación a la configuración del Derecho penal en la "sociedad del riesgo", Barcelona, 2005, pág. 186; el mismo, "Delimitación del riesgo típico en el delito contra la seguridad en el trabajo (art. $316 \mathrm{CP}$ ): especial atención a la relevancia jurídico-penal de la infracción del deber de vigilancia", Cuadernos de Política Criminal, 2008, n. ${ }^{\circ}$ 96, págs. 90 ss.; MORALES GARCÍA, O., "Régimen de responsabilidad penal derivada de la siniestralidad laboral en la ejecución de obras civiles", Actualidad Jurídica Uría Menéndez, 2005, n. ${ }^{\circ} 12$, pág. 36; FIGUEROA NAVARRO, M. C., "La responsabilidad penal por infracción de las normas de prevención de riesgos laborales", La Ley Penal, 2005, n. ${ }^{\circ}$ 19, págs. 57 ss.; PAVÍA CARDEL, J., "Responsabilidad penal por el siniestro laboral: una guía para la imputación personal”, La Ley Penal, 2005, n. ${ }^{\circ} 19$, págs. 29 ss.; MARTÍN LORENZO, M./ORTIZ DE URBINA GIMENO, I., "Los delitos contra los trabajadores en el ámbito de la construcción", en POZUELO PÉREZ, L. (coord.), Derecho penal de la construcción: aspectos urbanísticos, inmobiliarios y de seguridad en el trabajo, Granada, 2006, págs. 383 ss.; los mismos, "Guía InDret penal de la jurisprudencia sobre responsabilidad por riesgos laborales”, InDret, 2009, n. ${ }^{\circ} 2$, pág. 
colectivos, instrumentos, herramientas, espacios, en definitiva, todos aquellos recursos adecuados para prevenir los riesgos laborales, se añaden los que podríamos denominar medios intelectuales. Ésta es también la línea seguida por la jurisprudencia ${ }^{66}$ y con la que estoy de acuerdo ${ }^{67}$. En el contexto que nos ocupa, los medios materiales se corresponderían con mascarillas, pantallas protectoras, guantes, líquidos hidroalcohólicos, y cualquier otro medio profiláctico de los establecidos en la normativa desarrollada al respecto (ver $\mathrm{su}$ pra). Naturalmente, estos medios, muchos de ellos EPI, tendrán unas especificaciones técnicas precisas con diferentes niveles de seguridad en función del tipo de actividad que se desarrolle y la exposición al riesgo que pueda suponer. Junto a estos medios materiales individuales se deben incluir medios inmateriales como los relativos a la información al trabajador sobre las características del SARS-CoV-2, su modo

16; REVELLES CARRASCO, M., "El delito contra la vida y la salud de los trabajadores al hilo de la Sentencia de la Audiencia Provincial de Madrid de 20 de julio de 2006", Revista de Derecho Social, 2006, n. ${ }^{\circ} 38$, págs. 177 ss.; OLAIZOLA NOGALES, I., "Delitos contra los derechos de los trabajadores (arts. 316 y $317 \mathrm{CP}$ ) y su relación con los resultados lesivos", InDret, 2010, n. ${ }^{\circ}$ 2, págs. 14 s.; NAVAS-PAREJO ALONSO, M., "El papel de los arquitectos como responsables de los delitos contra la seguridad y salud de los trabajadores: la relevancia del análisis de su conducta", Aranzadi Social, 2011, n. ${ }^{\circ}$ 2, pág. 8; MARTÍNEZ-BUJÁN PÉREZ, C., Derecho penal económico y de la empresa, Parte especial, $6{ }^{\mathrm{a}}$ ed., Valencia, 2019, p. 919.

66 Así, MARTÍN LORENZO, M./ORTIZ DE URBINA GIMENO, I., "Guía InDret penal de la jurisprudencia sobre responsabilidad por riesgos laborales", InDret, 2009 , n. ${ }^{\circ}$ 2, págs. 15 s. También la Fiscalía General del Estado, Circular 4/2011, sobre criterios para la unidad de actuación especializada del Ministerio Fiscal en materia de siniestralidad laboral, págs. 18 s. Véanse, entre otras, STS 12-11-1998, SAP Sevilla 3-32010, SAP Alicante 14-7-2010, SAP Zaragoza 15-9-2010, SAP Valencia 31-5-2011, SAP Granada 23-9-2011, SAP Jaén 2-12-2011, SAP Sevilla 29-2-2012.

67 RODRÍGUEZ VÁZQUEZ, V., "Análisis de la responsabilidad penal de los técnicos en prevención de riesgos laborales, recursos preventivos y coordinadores de seguridad, a la luz de los arts. 316 y 317 del Código Penal", La Ley Penal, n. ${ }^{\circ}$ 103, julio-agosto 2013, pp. 51-68, p. 55. 
de transmisión y las mejores formas para evitar el contagio. Además de la formación, tanto por lo que respecta al uso de los equipos individuales como al comportamiento respecto a la colectividad (por ejemplo, en lo que se ha llamado la etiqueta respiratoria). Sin olvidar los medios organizativos que ante el riesgo vinculado al SARS-CoV-2 adquiere mayor importancia. En este sentido, la norma sobre la que ha de pivotar la organización del trabajo es el distanciamiento social fijado en 2 metros de perímetro alrededor de cada una de las personas. A partir de aquí se podrán organizar turnos de entrada y salida, turnos de trabajo, reducción de aforos en los lugares de trabajo, ordenación de la circulación de personas en los lugares de trabajo, entre otras. Y, por supuesto, medidas higiénicas y de limpieza estrictas. Todas estas medidas deberán adaptarse a la casuística de cada actividad laboral.

La segunda cuestión, directamente relacionada con la anterior, es qué se debe entender por "no facilitar". Nuevamente aquí podemos distinguir dos grupos de opinión diferenciados. Por una parte, un sector de la doctrina realiza una interpretación extensiva del verbo "facilitar", incluyendo en el mismo tanto su segunda acepción, conforme al Diccionario de la RAE, "proporcionar o entregar", como su primera acepción, es decir, "hacer fácil o posible la ejecución de algo o la consecución de un fin”. Desde el último punto de vista, no sólo integraría la conducta típica el hecho de no proporcionar a los trabajadores los medios materiales e inmateriales antes referidos, sino también el no vigilar su utilización por parte de los trabajadores, el no exigir, consecuentemente, su uso, e incluso, en algunas ocasiones, el no paralizar la actividad laboral que se está realizando sin la utilización de dichos medios $^{68}$. Desde este punto de vista la conducta típica del

68 Véase, AGUADO LÓPEZ, S., El delito contra la seguridad en el trabajo: artículos 316 y 317 del Código Penal, Valencia, 2002, pág. 197; LASCURAÍN SÁNCHEZ, J. A., "La imputación penal del accidente de trabajo", en AA.VV, Tutela penal de la seguridad en el trabajo, Cuaderno 
art. 316 CP no diferiría, en lo sustancial, de la obligación descrita en el art. 17.2 LPRL, que dispone: "el empresario deberá proporcionar a sus trabajadores equipos de protección individual adecuados para el desempeño de sus funciones y velar por el uso efectivo de los mismos". Pues bien, ésta es la interpretación defendida por la jurisprudencia española que, mayoritariamente, ha entendido la falta de vigilancia por parte del empresario o sus delegados como una forma de "no facilitar los medios" y, consecuentemente, como una conducta típica ${ }^{69}$. Sin embargo, la doctrina se ha inclinado por una interpretación más limitada de la expresión "no facilitar", restringiendo así el ámbito de este delito. Desde este punto de vista se puede decir que la mayoría de los autores

penales José María Lidón, Bilbao, 2006, pág. 51. Crítico en este punto con la redacción adoptada por el legislador por impedir precisamente pueda contener determinadas conductas típicas, se muestra MARTÍNEZ-BUJÁN PÉREZ, C., Derecho penal económico y de la empresa, Parte especial, 6. ${ }^{\text {a }}$ ed., Valencia, 2019, p. 920, señalando que "cuestión distinta es que la expresión utilizada por el legislador de 1995 para describir la conducta ('no facilitar los medios') no haya sido lo suficientemente flexible como para abarcar, sin dejar margen para la duda, cualquier clase de comportamientos activos e incluso para comprender algunos comportamientos omisivos de frecuente concurrencia (...). El legislador del nuevo $\mathrm{CP}(\ldots)$ ha simplificado la redacción típica en el sentido apuntado, con lo que se plantearán serios problemas para subsumir en el tipo conductas tales como la inadecuada selección, formación e información de los trabajadores en relación con los riesgos que implica la tarea concreta que se les asigna, la inadecuada organización de los ritmos de producción, la no exigencia a los trabajadores de las medidas de seguridad que requieren su colaboración o la no suspensión de la actividad".

69 Así lo señalan, MARTÍN LORENZO, M./ORTIZ DE URBINA GIMENO, I., "Guía InDret penal de la jurisprudencia sobre responsabilidad por riesgos laborales", InDret, 2009, n. ${ }^{\circ}$ 2, págs. 16 ss.; GARCÍA FIGUEROA, F., Los sujetos activos de los delitos contra la seguridad y salud en el trabajo. Especial consideración al sector de la construcción (Tesis doctoral), Getafe, 2011, pág. 67. Ésta parece ser también la postura sostenida por la Fiscalía General del Estado, Circular 4/2011, sobre criterios para la unidad de actuación especializada del Ministerio Fiscal en materia de siniestralidad laboral, págs. 18. Véanse, entre otras, SAP Pontevedra 30-3-2007, SAP Girona 30-11-2011. 
se acogen a la segunda de las acepciones del verbo "facilitar", excluyendo del ámbito de lo típico la "no vigilancia" y la "no exigencia" del uso de los medios previamente proporcionados a los trabajadores ${ }^{70}$. La principal razón que se esgrime es que lo contrario supondría superar el tenor literal del precepto, que marca en Derecho penal el límite de toda interpretación posible ${ }^{71}$. En efecto, en mi opinión, ésta es la conclusión correcta porque aunque se quiera incluir el "no vigilar", "no paralizar la actividad", "no exigir el uso de los medios" en la primera de las acepciones señaladas para "(no)

70 TERRADIllos BASOCO, J., Delitos contra la vida y la salud de los trabajadores, Valencia, 2002, pág. 84; el mismo, La siniestralidad laboral como delito, Albacete, 2006, págs. 79 ss.; el mismo, "Respuesta penal frente a la siniestralidad laboral", en AA.VV, Tutela penal de la seguridad en el trabajo, Cuadernos penales José María Lidón, Bilbao, 2006, págs. 32 ss.; HORTAL IBARRA, J. C., Protección penal de la seguridad en el trabajo: una aproximación a la configuración del Derecho penal en la "sociedad del riesgo", Barcelona, 2005, pág. 186; el mismo, "Delimitación del riesgo típico en el delito contra la seguridad en el trabajo (art. $316 \mathrm{CP}$ ): especial atención a la relevancia jurídico-penal de la infracción del deber de vigilancia”, Cuadernos de Politica Criminal, 2008, n. ${ }^{\circ}$ 96, págs. 95 ss.; MARTÍN LORENZO, M./ORTIZ DE URBINA GIMENO, I., "Los delitos contra los trabajadores en el ámbito de la construcción", en POZUELO PÉREZ, L. (coord.), Derecho penal de la construcción: aspectos urbanísticos, inmobiliarios y de seguridad en el trabajo, Granada, 2006, págs. 383 ss.; MARTÍN LORENZO, M./ORTIZ DE URBINA GIMENO, I., "Guía InDret penal de la jurisprudencia sobre responsabilidad por riesgos laborales", InDret, 2009, n. ${ }^{\circ} 2$, págs. 19 s.; OLAIZOLA NOGALES, I., "Delitos contra los derechos de los trabajadores (arts. 316 y $317 \mathrm{CP}$ ) y su relación con los resultados lesivos", InDret, 2010, n. ${ }^{\circ}$ 2, pág. 15; GARCÍA FIGUEROA, F., Los sujetos activos de los delitos contra la seguridad y salud en el trabajo. Especial consideración al sector de la construcción (Tesis doctoral), Getafe, 2011, págs. 68 ss.; RODRÍGUEZ VÁZQUEZ, V., "Análisis de la responsabilidad penal de los técnicos en prevención de riesgos laborales, recursos preventivos y coordinadores de seguridad, a la luz de los arts. 316 y 317 del Código Penal”, La Ley Penal, n. ${ }^{\circ}$ 103, julio-agosto 2013, pp. 51-68, pp. $55 \mathrm{~s}$.

71 OLAIZOLA NOGALES, I., "Delitos contra los derechos de los trabajadores (arts. 316 y $317 \mathrm{CP}$ ) y su relación con los resultados lesivos", InDret, 2010, n. $^{\circ}$ 2, págs. 14. 
facilitar", lo cierto es que no encajan. El motivo es que el tipo se refiere a facilitar medios y no a otra acción o cosa diferente. Además, esta interpretación de la conducta típica del art. 316 CP se puede apoyar precisamente también en el art. 17.2 LPRL. En dicho artículo se diferencian claramente dos acciones. Por una parte, "proporcionar (...) equipos" y, por otra, "velar por el uso efectivo de los mismos". La primera sería la coincidente con el término "facilitar", que no incluiría la segunda. No obstante podría plantearse que el deber de vigilancia constituye un presupuesto ineludible de la obligación de proporcionar formación a los trabajadores sobre el uso de los medios materiales o el desarrollo de su actividad y que, por tanto, el no vigilar el uso que aquellos hacen de estos, impedirá "corregir" a los trabajadores, lo que desde luego está abarcado por la acción de formar. Desde este punto de vista, se podría pensar que la falta de vigilancia constituye una conducta típica. Sin embargo, considero que aun realizando esta interpretación tampoco se podrá incluir en el tipo esa conducta. La acción típica será no informar, o no formar al trabajador en el uso de un determinado medio, lo que incluye no corregir un uso inadecuado. Fácticamente la acción de corrección presupone, al menos inicialmente, un control o vigilancia, pero normativamente sólo la falta de la primera y no la de la segunda, constituirá la conducta típica. En conclusión, la expresión "no facilitar los medios" impide que se pueda considerar que la falta de vigilancia, administrativamente sancionable ${ }^{72}$, sea también susceptible de integrar el tipo penal. En los casos de falta de vigilancia, estrictamente entendidos, los medios necesarios ya existen y son, en principio, suficientes. Ésta es una interpretación formalista pero garantista, que responde al principio de taxatividad, así como al principio de ultima ratio o intervención mínima, al permitir diferenciar la conducta típica de la infracción

72 La definición y clasificación de las infracciones (leves, graves y muy graves) puede verse en los arts. 46, 47 y 48 LPRL, mientras que las sanciones se contemplan en el art. 49 LPRL. 
administrativa. Ahora bien, conviene advertir aquí que aunque la falta de vigilancia del uso de los medios previamente proporcionados no baste para integrar el tipo del art. $316 \mathrm{CP}$, no significa que no se pueda tener en cuenta para fundamentar una infracción del deber de cuidado del empresario o de persona en quien éste delegue, y permitir la imputación del resultado lesivo o de la muerte del trabajador a título imprudente, conforme a los arts. 152 ó $142 \mathrm{CP}^{73}$.

La tercera cuestión es que no basta con que la persona obligada legalmente cometa una infracción de las normas de prevención de riesgos laborales consistente en no facilitar los medios necesarios para que los trabajadores desarrollen su actividad en condiciones adecuadas de seguridad e higiene. Para que concurra el tipo penal es necesario que esta conducta, tal y como acaba de exponerse, genere un resultado consistente en una puesta en peligro grave para la vida, salud e integridad física de los trabajadores. Nos encontramos ante un delito de peligro concreto ${ }^{74}$, pues tal y como se configura el

73 TERRADILlos BASOCO, J., Delitos contra la vida y la salud de los trabajadores, Valencia, 2002, pág. 84; el mismo, La siniestralidad laboral como delito, Albacete, 2006, págs. 79 ss.; el mismo, "Respuesta penal frente a la siniestralidad laboral", en AA.VV, Tutela penal de la seguridad en el trabajo, Cuadernos penales José María Lidón, Bilbao, 2006, págs. 32 ss.; HORTAL IBARRA, J.C., Protección penal de la seguridad en el trabajo: una aproximación a la configuración del Derecho penal en la "sociedad del riesgo", Barcelona, 2005, pág. 186; el mismo, "Delimitación del riesgo típico en el delito contra la seguridad en el trabajo (art. $316 \mathrm{CP}$ ): especial atención a la relevancia jurídico-penal de la infracción del deber de vigilancia", Cuadernos de Política Criminal, 2008, n. ${ }^{\circ}$ 96, págs. 98 ss.; MARTÍN LORENZO, M./ORTIZ DE URBINA GIMENO, I., "Los delitos contra los trabajadores en el ámbito de la construcción”, en POZUELO PÉREZ, L. (coord.), Derecho penal de la construcción: aspectos urbanísticos, inmobiliarios y de seguridad en el trabajo, Granada, 2006, págs. 383 ss.; OLAIZOLA NOGALES, I., "Delitos contra los derechos de los trabajadores (arts. 316 y $317 \mathrm{CP}$ ) y su relación con los resultados lesivos", InDret, 2010, n. ${ }^{\circ}$ 2, pág. 16.

74 Opinión de la doctrina mayoritaria, véase TERRADILLOS BASOCO, J., Delitos contra la vida y la salud de los trabajadores, Valencia, 2002, 
tipo, se exige determinar que la vida o salud de los trabajadores llegó a correr algún riesgo como consecuencia de la falta de medios preventivos. Ese peligro debe ser calificado como grave lo que está relacionado con la entidad del riesgo y con la proximidad de que llegue a concretarse en la muerte o lesión, a su vez grave, del trabajador, es decir, que la gravedad se predicaría tanto del riesgo como del hipotético resultado ${ }^{75}$. Aunque esta no es una opinión unánime pues hay quien considera que el término "grave" se refiere exclusivamente al riesgo pero no a la entidad de la probable lesión o enfermedad que, por tanto, puede ser leve y, no obstante, dar lugar a que concurra este delito ${ }^{76}$. En todo caso, el tipo penal no requiere

p. 91; MARTÍN LORENZO, M./ORTIZ DE URBINA GIMENO, I., "Los delitos contra los trabajadores en el ámbito de la construcción", en POZUELO PÉREZ, L. (coord.), Derecho penal de la construcción: aspectos urbanisticos, inmobiliarios y de seguridad en el trabajo, Granada, 2006, p. 340; CUENCA GARCÍA, M. J., "Prevención penal y extrapenal de la siniestralidad laboral", Estudios Penales y Criminológicos, vol. XXXIII (2013), pp. 1-57, p. 15.; MARTÍNEZ-BUJÁN PÉREZ, C., Derecho penal económico y de la empresa, Parte especial, 6. ${ }^{\mathrm{a}}$ ed., Valencia, 2019, p. 923; DE VICENTE MARTÍNEZ, R., Derecho penal del trabajo. Los delitos contra los derechos de los trabajadores y contra la Seguridad Social, Valencia, 2020, pp. 526 ss.

75 Así lo entiende, por ejemplo, DE VICENTE MARTÍNEZ, R., Derecho penal del trabajo. Los delitos contra los derechos de los trabajadores y contra la Seguridad Social, Valencia, 2020, pp. 521 ss.; MARTÍNEZBUJÁN PÉREZ, C., Derecho penal económico y de la empresa, Parte especial, 6. ${ }^{\text {a }}$ ed., Valencia, 2019, p. 924, quien señala que "parto de la base de que dicho adjetivo conviene a ambos aspectos: de un lado, expresa que el peligro ha de ser concreto; de otro lado, exige que ese peligro concreto afecte gravemente a la salud y a la integridad física (porque esta última exigencia carece de sentido en cuanto al bien jurídico vida). Por lo demás, esta interpretación (...) me parece político-criminalmente satisfactoria y acorde con la letra de la ley, aunque es cierto que lo más correcto gramaticalmente habría sido que el legislador hubiese precisado que el peligro deberá ir dirigido a vulnerar la vida o a causar una grave afectación a la salud o integridad física"; previamente, sobre esta cuestión y en este mismo sentido, LASCURAÍN SÁNCHEZ, J. A., La protección penal de la seguridad e higiene, Madrid, 1994, p. 391.

76 GARCÍA ARÁN, M., "Art. 316 CP. De los delitos contra los derechos de los trabajadores", en CÓRDOBA RODA, J./GARCÍA ARÁN, M. 
en ningún caso que ese riesgo se concrete precisamente en un resultado lesivo para dichos bienes jurídicos individuales. Por tanto, en la materia que nos ocupa, basta con comprobar que la exposición a los riesgos derivados del SARS-CoV-2 por parte del trabajador se produjeron en su lugar de trabajo o en el ejercicio de su actividad laboral y que al no contar con los medios de protección adecuados conforme a la normativa de prevención de riesgos laborales la posibilidad de que se llegase a infectar y con ello desarrollar la enfermedad de COVID-19 se planteó como real, cierta y próxima. De seguir a la doctrina mayoritaria en este apartado, sólo cuando se entienda que tanto el riesgo de contagio como la enfermedad han de ser graves, es necesario preguntarse si la enfermedad de COVID-19 puede considerarse como una daño grave para la salud de los trabajadores. Pues bien, para ello debemos tener en cuenta todo lo expuesto supra sobre la descripción del virus, su comportamiento y la enfermedad que puede llegar a desarrollar una persona tras ser infectada. En este sentido, esta valoración no puede dejar de tener en cuenta que los estudios clínicos, médicos, científicos sobre este virus y la enfermedad aparejada se están desarrollando prácticamente en tiempo real y que existen todavía numerosas incógnitas. No obstante, es claro que la enfermedad de COVID-19 presenta una complejidad y una gravedad elevadas. Esa mayor o menor gravedad está vinculada a factores individuales que tienen que ver, por lo que parece, con la edad (cuanta mayor edad más probabilidad de complicaciones severas), con las enfermedades de base que tenga la persona infectada y con el sexo (parece que la incidencia es mayor en hombres que en mujeres). Sin perjuicio de todas estas consideraciones y otras que se puedan llevar a cabo, lo cierto es que a la vista de los datos se puede concluir que el riesgo que entraña el virus para la salud o incluso la vida es grave, teniendo en cuenta

(dirs.), Comentarios al Código penal. Parte Especial, Tomo I, Madrid, 2004, p. 1315. 
además que no existe ni vacuna (en el momento de redacción de este artículo) ni tratamiento específico. Cabe añadir, desde mi punto de vista, que resulta ilustrativo el hecho de que el RD 664/1997, de 12 de mayo, sobre la protección de los trabajadores contra los riesgos relacionados con la exposición a agentes biológicos durante el trabajo, incluya entre dichos agentes a los coronaviridae, aunque clasificándolo en función del riesgo de infección en el grupo 2 de un total de 4 . No obstante, algunos autores consideran que debe entenderse encuadrado en el grupo $4^{77}$.

\section{Algunos sujetos activos del delito de infracción de las nor- mas de prevención de riesgos laborales en el contexto de la pandemia de COVID-19.}

1. La identificación de los posibles sujetos activos: del obligado originario a los técnicos de prevención de riesgos laborales y de la empresa privada al sector público

Una vez establecidos los límites de la conducta típica, queda por identificar a los posibles sujetos activos de este delito, o lo que es lo mismo, aclarar quiénes son o pueden ser "obligados legales" a proporcionar los medios referidos. Para determinar el círculo de posibles sujetos responsables será capital la LPRL, texto legal de referencia en esta materia. Pues bien, el art. 14 de la LPRL señala como primer y principal obligado a facilitar los medios destinados a la prevención de riesgos laborales al empresario. No nos da una definición de empresario pero todo nos indica que debemos inclinarnos por una definición poco formalista ${ }^{78}$. Además del

77 SALVADOR, N./PEÑALOSA, C., "Responsabilidad empresarial por contagio", Diario La Ley, N. ${ }^{\circ}$ 9631, 2020, pp. 1-6, p. 1.

78 Sobre el concepto de empresario, DE VICENTE MARTÍNEZ, R., Derecho penal del trabajo. Los delitos contra los derechos de los trabajadores y contra la Seguridad Social, Valencia, 2020, p. 469. 
empresario, el propio art. 14 LPRL establece que en el sector público corresponde a las Administraciones Públicas un deber de protección respecto del personal a su servicio. A continuación, se señalan los deberes específicos que en materia de prevención de riesgos laborales corresponden al empresario y, en su caso, a las Administraciones Públicas (arts. 16 a 28 LPRL). Entre ellos, cabe destacar a efectos del tipo penal objeto de estudio el art. 17 LPRL relativo a equipos de trabajo y medios de protección, el art. 18.1 LPRL relativo a la información de los trabajadores y el art. 19. LPRL relativo a la formación de los trabajadores. Así, el incumplimiento por parte del empresario de alguno de los deberes especificados en los citados artículos, dará lugar, siempre y cuando, claro está, se cumplan los demás elementos del tipo, a exigir responsabilidad penal al empresario conforme a lo establecido en el art. $316 \mathrm{CP}$ (o, en su caso, en el art. $317 \mathrm{CP}$ ). En el caso de las Administraciones Públicas, habrá que delimitar dentro del organigrama del organismo público la persona o personas que tenían competencias directivas en esta materia, que serán las originalmente responsables.

Estas disposiciones normativas despliegan todo su alcance en relación con los riesgos laborales derivados del SARS-CoV-2, viéndose además reforzadas por normas sectoriales promulgadas por el Gobierno con motivo de la pandemia de COVID-19. Así, a modo de ejemplo, podemos ver a continuación algunas de ellas. El RD-Ley 13/2020, de 7 de abril, por el que se adoptan determinadas medidas urgentes en materia de empleo agrario, contiene en su parte expositiva que "para poder acceder a este tipo de contratos, el empresario deberá asegurar en todo momento la disponibilidad de medios de prevención apropiados frente al COVID-19”. A continuación, en su parte dispositiva, el art. 4 establece que "el empresario deberá asegurar en todo momento la disponibilidad de medios de prevención apropiados frente al COVID-19". En el sector público se puede citar, entre otras, la Orden JUS/394/2020, de 8 de mayo, por la que se aprueba el 
esquema de seguridad laboral y el plan de desescalada para la Administración de Justicia ante el COVID-19, en cuyo punto 1.7 del Anexo I, Medidas de seguridad laboral durante la pandemia COVID-19 y para la transición y recuperación progresiva de la actividad ordinaria de la Administración de Justicia, dispone que "las alternativas para mejorar la eficiencia de las medidas de protección colectiva se adoptarán por los titulares de los edificios y sedes judiciales, y se comunicarán a los respectivos servicios de prevención para su idoneidad en su combinación con otras medidas y, posteriormente, a las Gerencias Territoriales u órganos equivalentes en las CCAA con competencia transferida para su suministro e implantación. Las personas u órganos responsables de trabajadores no vinculados al mismo órgano administrativo titular de los edificios donde se realicen actividades laborales concurrentes, deberán garantizar el conocimiento y la coordinación de las medidas preventivas adoptadas".

Nos encontramos, por tanto, ante un delito especial propio $^{79}$, que sólo puede ser cometido por quien tiene obligación legal de facilitar los medios preventivos, lo que, como quedó dicho, corresponde originariamente al empresario (en un sentido material) y en el ámbito de las Administraciones Públicas a quien tiene atribuidas estas funciones, ocupando una posición directiva relevante.

A partir de aquí surge la duda de si, además de las personas señaladas, existen otras que por razón de su cargo, también pueden llegar a ser responsables penalmente por infracción de las normas de prevención de riesgos laborales. Ciertamente, aquellas otras personas que ejercen una posición directiva en la empresa y actúan, por tanto, "en lugar"

79 Sobre esta caracterización véase, DE VICENTE MARTÍNEZ, R., Derecho penal del trabajo. Los delitos contra los derechos de los trabajadores y contra la Seguridad Social, Valencia, 2020, pp. 466 s.; MARTÍNEZBUJÁN PÉREZ, C., Derecho penal económico y de la empresa, Parte especial, 6. ${ }^{\text {a }}$ ed., Valencia, 2019, p. 918. 
del empresario, pueden ser igualmente responsables penalmente. Sintéticamente, DE VICENTE MARTÍNEZ señala que "sujeto activo de los delitos contra la seguridad en el trabajo es tanto el obligado principalmente a facilitar los medios, como quienes -bajo sus órdenes- han de ocuparse concretamente de esa facilitación. Ello permite responsabilizar a cuantas personas han de poner en manos de los trabajadores el equipo de personas y de más material y la información que garantice la seguridad de éstos. La LPRL y la normativa concordante crean todo un entramado de seguridad que, sin eximir de responsabilidad al empresario, constituye en eventuales garantes también a los escalones más próximos a la ejecución misma de los diferentes trabajos" $"$. Junto a ellas, me interesa aquí detenerme en los técnicos de los servicios de prevención de riesgos laborales, que han sido nombrados prolijamente en la normativa de referencia elaborada y publicada desde el Gobierno de España para hacer frente a la pandemia. Recordemos que precisamente el documento "Procedimiento de actuación para los servicios de prevención de riesgos laborales frente a la exposición al SARSCoV-2", publicado por el Ministerio de Sanidad por primera vez el día 28 de febrero de 2020, siendo objeto de sucesivas revisiones y actualizaciones desde entonces hasta llegar a la versión actualmente en vigor, de 30 de abril de 2020, pone de manifiesto el relevante papel que han de jugar los servicios de prevención en la contención de la pandemia ${ }^{81}$.

Pues bien, conforme al art. 30.1 LPRL, el empresario puede delegar en los propios trabajadores, en servicios internos de prevención formados por personal especializado o en servicios externos a la empresa las funciones de prevención. Es precisamente en esta disposición legal y en otras que la

80 DE VICENTE MARTÍNEZ, R., Derecho penal del trabajo. Los delitos contra los derechos de los trabajadores y contra la Seguridad Social, Valencia, 2020, p. 475.

81 Véase supra. 
desarrollan donde la doctrina se apoya para afirmar que los delegados del empresario en materia de prevención son también obligados legales a efectos del art. $316 \mathrm{CP}$, existiendo una tendencia generalizada tanto en la propia doctrina como en la jurisprudencia a atribuir potencialmente responsabilidad penal a los técnicos en prevención de riesgos laborales ${ }^{82}$. Sin embargo, una delimitación adecuada de las competencias de estos sujetos respecto de las competencias del empresario a través de un análisis detallado de la legislación relativa a prevención de riesgos laborales y de las funciones que de facto asumen, nos conduce a limitar extraordinariamente su posible responsabilidad penal, hasta el punto, en mi opinión, de convertirla en muchos casos en residual, a pesar del "ape1lido" de estos profesionales ${ }^{83}$. Para que los delegados del empresario puedan ser considerados responsables penales deben

82 DÓPICO GÓMEZ-ALLER, J., “¿Qué salvar del art. 318 CP? La responsabilidad de administradores y encargados del servicio en los delitos contra los derechos de los trabajadores 'atribuidos a una persona jurídica'. Consideraciones de lege ferenda", en ÁLVAREZ GARCÍA, F.J. (Dir.), La adecuación del Derecho penal español al ordenamiento de la Unión Europea. La Política criminal europea, Valencia, 2008, pp. 563 s.; MARTÍN LORENZO, M./ORTIZ DE URBINA GIMENO, I., "Guía InDret penal de la jurisprudencia sobre responsabilidad por riesgos laborales", InDret, 2009, n. ${ }^{\circ}$ 2, pp. 27 ss.; GARCÍA FIGUEROA, F., Los sujetos activos de los delitos contra la seguridad y salud en el trabajo. Especial consideración al sector de la construcción (Tesis doctoral), Getafe, 2011, p. 53. MARTÍNEZ-BUJÁN PÉREZ, C., Derecho penal económico y de la empresa, Parte especial, 6. ${ }^{\mathrm{a}}$ ed., Valencia, 2019, p. 919; DE VICENTE MARTÍNEZ, R., Derecho penal del trabajo. Los delitos contra los derechos de los trabajadores y contra la Seguridad Social, Valencia, 2020, pp. 485 ss. Véanse, entre otras, SAP Barcelona 21-7-2008, SAP Sevilla 17-2-2009.

83 En muchos casos, da la sensación que lo determinante en la condena penal para los tribunales de justicia es precisamente que estas personas se denominen técnicos en prevención de riesgos laborales, dando lugar así a un insoportable Derecho penal de autor, en el que la mera presencia de este profesional en el centro en el que se constata un peligro para la vida y salud de los trabajadores a consecuencia de la falta de medios adecuados determina ipso facto su responsabilidad penal conforme al art. 316 ó siguientes del CP. 
estar obligados a "facilitar los medios necesarios" a los que se refiere el art. $316 \mathrm{CP}$ como he señalado anteriormente ${ }^{84}$. Si hacemos una lectura completa de la LPRL y del RD 39/1997, de 17 de enero, por el que se aprueba el Reglamento de Servicios de Prevención, no está claro, al menos, no es indubitado, que a dichos delegados les corresponda el deber de facilitar los medios necesarios o, cuando menos, todos los medios (de la clase que sean) que garanticen la seguridad y la salud de los trabajadores.

En relación con los servicios de prevención externos a la empresa y contratados por el empresario, el art. $31 \mathrm{LPRL}$ establece un elenco de competencias en apariencia muy amplio pero que si se lee con detenimiento no lo es tanto. Realmente, los servicios de prevención tienen asignadas funciones de "asesoramiento", "asistencia", "apoyo" del empresario en materia de prevención, focalizándose además en las tareas de "evaluación" de riesgos y "planificación" de la actividad preventiva. Esto se ve confirmado por los arts. 19 y 20 RD 39/1997, que aunque parece que no cierran la posibilidad de que el servicio de prevención ajeno asuma directamente la obligación de proporcionar medios preventivos, lo normal es que en el concierto de la actividad preventiva suscrito entre la empresa y el servicio de prevención se consignen funciones de asesoramiento, tales como "identificar, evaluar y proponer las medidas correctoras" en la materia que corresponda. Una mayor concreción de las funciones que corresponden a las personas que trabajan en el servicio de prevención es la que se establece en los arts. 34 ss. RD 39/1997, en los que se distinguen entre funciones de nivel básico, intermedio y superior. Aunque en algún caso se establece como función "realizar actividades de información y formación básica de trabajadores" [art. 36.1 d) RD 39/1997], nuevamente se

84 Sobre la posibilidad de delegación y transferencia de responsabilidad en este delito, véase MARTÍNEZ-BUJÁN PÉREZ, C., Derecho penal económico y de la empresa, Parte especial, 6. ${ }^{\mathrm{a}}$ ed., Valencia, 2019, p. 927. 
observa cómo la mayoría de las funciones que se describen son relativas a promover actuaciones preventivas (art. 35.1 RD 39/1997), a la evaluación de riesgos, a la planificación de la actividad preventiva, a la vigilancia y control (entendido como inspección) de la evolución de los riesgos y de la eficacia de los planes de prevención implementados para en su caso proponer mejoras (arts. 35, 36 y 37 RD 39/1997). Los deberes de evaluar los riesgos y de planificar la actividad preventiva son, todo lo más, presupuestos para facilitar los medios, pero no constituyen en sí mismas la acción a la que obliga el art. 316 CP. Consecuentemente, los responsables de los servicios de prevención ajenos a la empresa, y en concreto, los técnicos en prevención, no tienen por qué ser considerados ad initium obligados legales del art. $316 \mathrm{CP}^{85}$. Obviamente, si se parte,

85 En este mismo sentido, véase Fiscalía General del Estado, Circular 4/2011, sobre criterios para la unidad de actuación especializada del Ministerio Fiscal en materia de siniestralidad laboral, págs. 7 ss.; NAVARRO CARDOSO, F./LOSADA QUINTÁS, J., "La autoría en los delitos contra la seguridad e higiene en los trabajos", Actualidad Penal, 2001, n. ${ }^{\circ}$ 40, p. 965; GÓMEZ MARTÍN, V., "El enigmático art. 318 CP: diez cuestiones controvertidas", en MIR PUIG, S./CORCOY BIDASOlO, M. (dirs.), HORTAL IBARRA, J.C. (coord.), Protección penal de los derechos de los trabajadores: seguridad en el trabajo, tráfico ilegal de personas e inmigración clandestina, Madrid, 2009, p. 251; LASCURAIN SÁNCHEZ, J. A., "La imputación penal del accidente de trabajo", en AA.VV., Tutela penal de la seguridad en el trabajo, Cuaderno penales José María Lidón, Bilbao, 2006, p. 50 s. En sentido contrario, MARTÍN LORENZO, M./ORTIZ DE URBINA GIMENO, I., "Los delitos contra los trabajadores en el ámbito de la construcción”, en POZUELO PÉREZ, L. (coord.), Derecho penal de la construcción: aspectos urbanísticos, inmobiliarios y de seguridad en el trabajo, Granada, 2006, p. 418 ss.; TERRADILLOS BASOCO, J., La siniestralidad laboral como delito, Albacete, 2006, p. 76; DE VICENTE MARTÍNEZ, R., "Sujetos responsables de la seguridad y salud laboral en el trabajo en el ámbito laboral y en el ámbito penal. En especial la responsabilidad penal de los técnicos en prevención de riesgos laborales", Actualidad Penal, 2003, n. ${ }^{\circ}$ 1, pp. 333 ss.; HORTAL IBARRA, J. C., Protección penal de la seguridad en el trabajo: una aproximación a la configuración del Derecho penal en la "sociedad del riesgo", Barcelona, 2005, pp. 257 ss.; AGUADO LÓPEZ, S., El delito contra la seguridad en el trabajo: artículos 316 y 317 
como lo hace la jurisprudencia, de una interpretación extensiva de la expresión "facilitar los medios necesarios" incluyendo también la vigilancia en el uso que los trabajadores hacen de aquéllos, entonces los técnicos en prevención quedarán automáticamente abarcados en el elenco de posibles sujetos activos del delito, pues la LPRL y el RD 39/1997 les atribuyen expresamente tareas en este sentido (art. 31 LPRL y arts. 19 y 20 RD 39/1997). Pero como ya expuse, esa es una interpretación que, por distintas razones, no comparto ${ }^{86}$.

En conclusión, sujeto activo del art. $316 \mathrm{CP}$ puede serlo, en principio, el empresario y no los técnicos en prevención que se integran en los servicios de prevención contratados por la empresa. Estos últimos podrán ser abarcados por el círculo de sujetos activos del art. $316 \mathrm{CP}$ cuando no sólo desempeñen las tareas de evaluación y planificación de las medidas preventivas en una empresa, sino cuando a través del concierto asuman directamente las funciones de prevención, es decir, el proporcionar todos o parte de los medios preventivos a los trabajadores de la empresa, lo que significará que dispondrán de autonomía de decisión y de gestión, al menos en lo que a esta parcela se refiere, en el seno de la empresa que los contra$\mathrm{ta}^{87}$. Y esto último es ciertamente muy poco frecuente.

del Código Penal, Valencia, 2002, pp. 329 s.; LASCURAÍN SÁNCHEZ, J. A., "La prevención penal de los riesgos laborales: cinco preguntas", en CARBONELL MATEU, J.C./DEL ROSAL BLASCO, B./MORILLAS CUEVA, L./ORTS BERENGUER, E./QUINTANAR DÍEZ, M. (coords.), Estudios Penales en Homenaje al profesor Cobo del Rosal, Madrid, 2005, pp. 580 ss.; GARCÍA FIGUEROA, F., Los sujetos activos de los delitos contra la seguridad y salud en el trabajo. Especial consideración al sector de la construcción (Tesis doctoral), Getafe, 2011, pp. 136; RODRÍGUEZ VÁZQUEZ, V., "Análisis de la responsabilidad penal de los técnicos en prevención de riesgos laborales, recursos preventivos y coordinadores de seguridad, a la luz de los arts. 316 y 317 del Código Penal", La Ley Penal, $n .^{\circ}$ 103, julio-agosto 2013, pp. 51-68, pp. 56 ss.

86 Véase supra.

87 En este mismo sentido véase, Fiscalía General del Estado, Circular 4/2011, sobre criterios para la unidad de actuación especializada del Ministerio Fiscal en materia de siniestralidad laboral, p. 9. 


\section{Delimitación de la responsabilidad penal entre em-}

presario y técnicos de prevención de riesgos laborales: cuestiones de autoría y participación, principios de división del trabajo y de confianza

Delimitados los ámbitos de competencia que corresponden al empresario y a los técnicos en prevención de riesgos laborales, procede por último analizar la división de trabajo que media entre ellos y determinar la relación de autoría y participación para cada uno de sus actos.

Por lo visto hasta ahora, lo habitual es que los técnicos en prevención que contrate la empresa se ocupen de tareas de evaluación de riesgos y planificación de medidas preventivas, correspondiendo al empresario la ejecución de los planes de prevención, facilitando los medios establecidos en dichos planes a sus trabajadores. En estos casos, el empresario que no facilita los medios a sus trabajadores es quien determina objetiva y positivamente el hecho ${ }^{88}$, pues es quien con su

88 Sobre la teoría de la determinación objetiva y positiva del hecho, véase LUZÓN PEÑA, D. M., "Autoría e imputación objetiva en el delito imprudente: valoración de las aportaciones causales (Comentario a la STS de 27 de enero de 1984)", Revista de Derecho de la Circulación, 1984, pp. 275 ss.; el mismo, "La 'determinación objetiva del hecho'. Observaciones sobre la autoría en delitos dolosos e imprudentes de resultado", Anuario de Derecho Penal y Ciencias Penales, 1989, Tomo 42, pp. 889 ss.; DÍAZ Y GARCÍA CONLLEDO, M., La autoría en Derecho Penal, Barcelona, 1991; el mismo, "La autoría en Derecho penal. Caracterización general y especial atención al Código Penal colombiano", Derecho Penal y Criminología, 2004, p. 44; el mismo, "La influencia de la teoría de la autoría (en especial de la coautoría) de Roxin en la doctrina y en la jurisprudencia españolas. Consideraciones críticas", Revista Nuevo Foro Penal, n. ${ }^{\circ}$ 76, p. 33 ss.; DÍAZ Y GARCÍA CONLLEDO, M./DE VICENTE REMESAL, J., "Autoría o participación en determinados supuestos de 'vigilancia' (comentarios a la STS de 21 de febrero de 1989) (Pte. Bacigalupo Zapater)”, Poder Judicial, 1992, n. ${ }^{\circ}$ 27, pp. 189 ss.; ROSO CAÑADILLAS, R., Autoría y participación imprudente, Granada, 2002, pp. 580 ss.; DURÁN SECO, I., La coautoría en Derecho Penal: aspectos esenciales, León, 2003, pp. 45 ss.; GARCÍA MOSQUERA, M., La estafa de seguro, Madrid, 2006, p. 256; RODRÍGUEZ VÁZQUEZ, V., Responsabilidad penal en el ejercicio de actividades médico-sanitarias, 
actuación omisiva determina el sí y el como del hecho, la puesta en peligro de los trabajadores, creando un riesgo inexistente o incrementando un riesgo que hasta ese momento estaba o se suponía contenido. Por lo tanto, el empresario es el autor del hecho, pudiendo a partir de aquí darse varias combinaciones. En primer lugar, puede ocurrir que el empresario reciba una evaluación y planificación adecuada por parte de los servicios de prevención con los que ha contratado esta prestación, es decir, éstos han cumplido correctamente con sus obligaciones de asesoramiento y apoyo en materia preventiva y, sin embargo, aquél decida no proporcionar los medios materiales y/o inmateriales necesarios poniendo así en peligro la vida y/o salud de los trabajadores. En este caso, sólo el empresario podría ser responsabilizado en concepto de autor por un delito doloso (otra cuestión es la clase de dolo) del art. 316 CP. En segundo lugar, manteniendo el supuesto anterior, puede ser que el empresario no proporcione, por error sólo a él atribuible, los medios necesarios, en cuyo caso sólo él respondería como autor imprudente conforme al art. $317 \mathrm{CP}$. El tercer supuesto, más problemático, sería aquel en que el empresario no proporciona los medios necesarios debido a un error provocado por una incorrecta evaluación de riesgos o planificación de la actividad preventiva por parte de los responsables de los servicios de prevención contratados. En este caso hay que valorar si se da una "relación de instrumentalización", la cual supone una dependencia del sujeto de delante, de quien realiza el hecho de propia mano

Madrid, 2012, pp. 337 ss.; ESCOBAR VÉLEZ, S., La responsabilidad penal por productos defectuosos, Valencia, 2012, p. 99; ALPACA PÉREZ, A., Delitos tributarios y aduaneros, Lima, 2015, pp. 578 y s.; FRANCÉS LECUMBERRI, P., El desvalor penal de la contabilidad creativa y otras problemáticas a la luz del bien jurídico protegido en el art. 290 CP, Valencia, 2017, p. 254; PÉREZ-SAUQUILLO MUÑOZ, C., "Reflexiones y críticas sobre el pensamiento de la acumulación", $L L P$ 2017-128, pp. 1-32, pp. 27 y s.; TORRES CADAVID, N., La responsabilidad penal del asesor fiscal. Problemas de autoría y participación en el delito de defraudación tributaria, Valencia, 2019, p. 400. 
(en este caso, por todo lo explicado, el empresario), respecto del sujeto de atrás, más alejado desde el punto de vista fáctico o espacio-temporal, del hecho (en este caso, el técnico en prevención de riesgos laborales). Es decir, se trata de determinar si existe o no autoría mediata imprudente ${ }^{89}$.

Para explicar la instrumentalización como requisito estructural de la autoría mediata hay que determinar qué es lo que debe conocer cada uno de los sujetos intervinientes, lo cual depende de las competencias que cada uno asume, pero también de la clase de división de trabajo en la que se encuentren y, en consecuencia, del valor que el principio de confianza pueda tener en sus actuaciones ${ }^{90}$. En mi opinión, la división de trabajo entre el empresario y el técnico de prevención es vertical, siendo el empresario el superior jerárquico respecto al técnico de prevención. Ciertamente, si adoptásemos como criterio único para calificar la división de vertical u horizontal el de la formación, la posición de cada uno de los sujetos se invertiría, sin embargo, siendo el de la formación un criterio fundamental, no es el único, puesto que hay que tener en cuenta también el lugar que ocupan dichos sujetos en el organigrama empresarial ${ }^{91}$. Combinando ambos

89 Sobre la admisión de la autoría mediata conforme al CP español véase HERNÁNDEZ PLASENCIA, J. U., La autoría mediata en Derecho penal, Granada, 1996, p. 334; PÉREZ MANZANO, M., Autoría y participación imprudente en el Código penal de 1995, Madrid, 1999, p. 72; DÍAZ Y GARCÍA CONLLEDO, M., "La autoría mediata. Con una especial referencia a los delitos socioeconómicos y contra el medio ambiente", Documentos Penales y Criminológicos, 2001, 1, p. 54; ROSO CAÑADILlAS, R., Autoría y participación imprudente, Granada, 2002 , p. 545.

90 Véase ROSO CAÑADILLAS, R., Autoría y participación imprudente, Granada, 2002, p. 558; RODRÍGUEZ VÁZQUEZ, V., Responsabilidad penal en el ejercicio de actividades médico-sanitarias, Madrid, 2012, pp. 418 ss.

91 Sobre esta cuestión, en profundidad, véase RODRÍGUEZ VÁZQUEZ, V., Responsabilidad penal en el ejercicio de actividades médico-sanitarias, Madrid, 2012, pp. 210 ss. 
criterios, considero que el empresario ocupa una posición jerárquicamente superior porque es él quien contrata los servicios de prevención y, por lo tanto, quien los elige, y es a él, en definitiva, al que le corresponde la última decisión en relación con los medios que se deban facilitar o no a los trabajadores, además de que el empresario es quien tiene el poder económico en la empresa. Esa relación jerárquica conlleva unos deberes, denominados por la doctrina, secundarios, que el superior está obligado a observar en su conducta respecto al subordinado. En concreto, el empresario debe ser diligente y cuidadoso en la elección y contratación del servicio de prevención para su empresa. Posteriormente, debe llevar a cabo una vigilancia y control de la actividad que desarrollen los servicios de prevención. Si bien es cierto que, debido a la diferente formación de unos y otros en materia preventiva (diferencia que generalmente se agudizará cuanto más compleja sea la actividad empresarial), ese deber de supervisión se va a cumplir con un seguimiento mínimo de dicho servicio de prevención. Ahora bien, si el empresario cumple con dichos deberes y no existe ninguna circunstancia que le deba hacer dudar sobre la fiabilidad de la labor de asesoramiento y asistencia de los técnicos en prevención, entonces podrá confiar en la corrección de la actuación de aquéllos. Pues bien, en este caso se podría afirmar que el técnico de prevención es autor mediato doloso, o lo que será más habitual, imprudente conforme a los arts. 316 o 317 CP. Si por el contrario no se da tal instrumentalización, porque el empresario, el obligado a facilitar los medios, no puede confiar en la actuación del técnico de prevención, es decir, está incurriendo, a su vez, en una imprudencia, entonces la solución sería calificar al empresario como autor imprudente mientras que el técnico en prevención será un partícipe imprudente, posiblemente un cooperador necesario, conforme al CP actual, impune.

Estas soluciones se verán modificadas si, de acuerdo con el concierto firmado entre el empresario y el servicio de prevención, el técnico en prevención asume la obligación de 
facilitar los medios necesarios a los trabajadores en cumplimiento de la evaluación y planificación realizadas con antelación. Para que dicho concierto sea efectivo, es necesario que el empresario ponga a disposición de dichos servicios los recursos económicos y de otro tipo precisos para el desarrollo de aquellas funciones y que les otorgue en esta materia cierta autonomía. En este supuesto se produce una auténtica delegación de la obligación de facilitar medios y como he indicado anteriormente, los técnicos en prevención que han asumido estas competencias pasan a integrarse en el círculo de posibles sujetos activos. Sin embargo, no por ello se ve modificada la división de trabajo que media entre el empresario y el técnico en prevención de riesgos laborales. Se trata de una división vertical, en la que el empresario sigue siendo el superior jerárquico del técnico. Es esa relación jerárquica la que obliga al empresario a, en primer lugar, cerciorarse nuevamente de que los técnicos que se ocupan de la prevención en los términos que acabamos de señalar reúnen los requisitos necesarios para el desempeño de dichas funciones, es decir, ha de ser diligente en la elección. En segundo lugar, debe supervisar, al menos periódicamente, la actividad de los servicios de prevención contratados ${ }^{92}$. En este contexto, el cumplimiento de estos deberes por parte del empresario dará lugar a que ante la falta de medios que ponga en peligro la vida y/o salud de los trabajadores, sólo se considere autor al técnico de prevención, pues sólo éste es quien determina objetiva y positivamente el hecho. Habrá que valorar, en el plano subjetivo, si esa conducta es dolosa o imprudente. Sin embargo, la solución será diferente en el caso de que el empresario no pueda confiar en la corrección de las personas en quienes delegó las funciones preventivas. Esto se producirá,

92 MARTÍN LORENZO, M./ORTIZ DE URBINA GIMENO, I., "Guía InDret penal de la jurisprudencia sobre responsabilidad por riesgos laborales", InDret, 2009, n. ${ }^{\circ}$ 2, p. 35; OLAIZOLA NOGALES, I., "Delitos contra los derechos de los trabajadores (arts. 316 y $317 \mathrm{CP}$ ) y su relación con los resultados lesivos", InDret, 2010, n. ${ }^{\circ}$ 2, p. 19. 
generalmente, cuando el superior jerárquico no haya cumplido con aquellos deberes de los que se hace depender la vigencia del principio de confianza al tiempo que los técnicos en prevención de riesgos dejan de facilitar total o parcialmente los medios necesarios. Siendo esto así, revierte en el empresario la obligación de facilitar los medios necesarios, y nos encontramos con dos sujetos, empresario y técnico en prevención, que tienen el mismo deber de facilitar medios. En la hipótesis de que tanto el empresario como el técnico en prevención en el que aquél delegó dejen de facilitar los "mismos" medios generando con ello el peligro requerido por el tipo, estaríamos, en mi opinión, ante un supuesto de pluriautoría en el que cada una de las acciones individualmente consideradas cumplen el requisito exigido para ser calificadas de autoría. Dicho de otra forma, cada una de las acciones es suficiente para producir el hecho por sí sola, ya que cumple con el criterio de determinación objetiva y positiva del hecho ${ }^{93}$. Esta misma solución se adoptará en el supuesto de que el empresario, cumpliendo con su deber de vigilancia, constate que el técnico no proporciona los medios adecuados, ya que tampoco aquí podrá confiar en una correcta actuación del delegado.

En los casos que acabo de plantear y que son reconducidos a la pluriautoría, caben distintas combinaciones de dolo e imprudencia. Así, tanto para el supuesto en el que el empresario no vigile como para el caso de que vigile y compruebe que los técnicos no proporcionan los medios necesarios, la conducta del primero podrá ser calificada, en función de las circunstancias del caso (formación del empresario, complejidad de la actividad empresarial y de las acciones preventivas, etc.), como imprudente o dolosa (generalmente con dolo eventual), pudiendo calificarse de igual manera la

93 Véase ROSO CAÑADILLAS, R., Autoría y participación imprudente, Granada, 2002, p. 561; DURÁN SECO, I., La coautoría en Derecho Penal: aspectos esenciales, León, 2003, p. 285. 
conducta del delegado. Algunos autores adoptan una postura diferente, señalando que si el empresario vigila al delegado y constata que éste no facilita los medios necesarios, entonces será autor del delito del art. $316 \mathrm{CP}$, porque incumple su deber de facilitar dichos medios; sin embargo, si no vigila y no conoce que el delegado no facilita los medios necesarios, su conducta no encaja en el art. 316, al menos no como autor ${ }^{94}$. Desde mi punto de vista, es cuando menos extraño que el empresario que no vigila el cumplimiento de sus funciones por parte del delgado, resulte jurídico-penalmente "más beneficiado" que aquél que lo hace. Por otra parte, el hecho de que el empresario conozca o deje de conocer que el delegado haya facilitado o no los medios necesarios, no cambia su calificación como autor o partícipe en el hecho. Ésta es una cuestión referida al desvalor subjetivo de la acción pero que no intervendrá en un elemento eminentemente objetivo como la autoría (y la participación).

Sin embargo, junto a los casos que he resuelto como de pluriautoría, considero que también son posibles casos de coautoría y autoría accesoria. Para poder afirmar la coautoría se exige que se cumpla un requisito objetivo y un requisito subjetivo. El requisito objetivo de la coautoría, la codeterminación objetiva del hecho, exige, en primer lugar, que concurran dos acciones o más en la producción del hecho delictivo. En segundo lugar, se debe comprobar la insuficiencia de cada una de ellas para producir el hecho por sí sola. En tercer lugar, se debe comprobar que la conjunción de las acciones realizadas por los distintos intervinientes, y sólo esa conjunción, es la que co-determina objetiva y positivamente

94 Véase OLAIZOLA NOGALES, I., "Delitos contra los derechos de los trabajadores (arts. 316 y $317 \mathrm{CP}$ ) y su relación con los resultados lesivos", InDret, 2010, n. ${ }^{\circ}$ 2, pp. 17, 20. Por su parte, DÍAZ Y GARCÍA CONLLEDO, M., "El delito contra la seguridad en el trabajo: algunos problemas del dolo y la imprudencia, concursales y relativos al art. 318 del Código Penal", Poder Judicial, n. ${ }^{\circ} 80$, 2005, pp. 30 ss., parece considerar al empresario como un partícipe en estos supuestos. 
el hecho ${ }^{95}$. El requisito subjetivo de la coautoría exige la presencia de un acuerdo que debe mediar entre los intervinientes que han realizado una acción que cumple con los criterios anteriormente señalados ${ }^{96}$. Por su parte, la autoría accesoria se caracteriza por cumplir el requisito objetivo que se debe dar en los supuestos de coautoría. Es decir, concurren varias conductas (dolosas o imprudentes) de manera que la unión de todas y cada una de ellas es la que produce el hecho. La diferencia entre ambas figuras se plantea en relación con el elemento subjetivo, el acuerdo ${ }^{97}$. En la autoría accesoria no

95 Véase DÍAZ Y GARCÍA CONLLEDO, M., La autoría en Derecho penal, Barcelona, 1991, p. 667; LUZÓN PEÑA, D-M./DÍAZ Y GARCÍA CONLLEDO, M., "Determinación objetiva y positiva del hecho y realización típica como criterios de autoría”, Anuario de la Facultad de Derecho de la Universidad de Alcalá de Henares, 2000, n. ${ }^{\circ} 8$, p. 74; los mismos, "Objektive positive Tatbestimmung und Tabestandsverwirklichung als Täterschaftsmerkmale", en SCHUNEMANN, B./ACHENBACH, H./ BOTTKE, W./HAFFKE, B./RUDOLPHI, H-J.(eds.), Festschrift für Claus Roxin, Berlin, New York, 2001, p. 596; los mismos, "Determinación objetiva y positiva del hecho y realización típica como criterios de autoría", Revista de Derecho Penal Contemporáneo, 2003, n. ${ }^{\circ} 2$, p. 112; siguiendo a estos autores, ROSO CAÑADILLAS, R., Autoría y participación imprudente, Granada, 2002, p. 580; DURÁN SECO, I., La coautoría en Derecho Penal: aspectos esenciales, León, 2003, p. 279; RODRÍGUEZ VÁZQUEZ, V., Responsabilidad penal en el ejercicio de actividades médico-sanitarias, Madrid, Marcial Pons, 2012, pp. 384 s.

96 Véase DÍAZ Y GARCÍA CONLLEDO, M., La autoría en Derecho penal, Barcelona, 1991, pp. 653 ss.; ROSO CAÑADILLAS, R., Autoría y participación imprudente, Granada, 2002, p. 580; GUTIÉRREZ RODRÍGUEZ, M., La responsabilidad penal del coautor, Valencia, 2001, pp. 126 ss.; BOLEA BARDON, C., Autoría mediata en Derecho penal, Valencia, 2000, pp. 31, 37 ss. En contra de la necesidad del acuerdo como elemento integrante de la coautoría, véase GUANARTEME SÁNCHEZ LÁZARO, F., Intervención delictiva e imprudencia, Granada, 2004, pp. 193 ss.; GARCÍA DEL BLANCO, M. ${ }^{a}$ V., La coautoría en Derecho penal, Valencia, 2006, pp. 432 ss. En la coautoría imprudente el acuerdo debe ir referido exclusivamente a la realización de la acción descuidada. Sobre esta cuestión, en profundidad, ROSO CAÑADILLAS, R., Autoría y participación imprudente, Granada, 2002, p. 587.

97 Sobre la función del acuerdo, con una propuesta particular sobre el papel que debe desempeñar en relación con la coautoría y la autoría 
existe un acuerdo entre los sujetos que realizan las aportaciones objetivamente determinantes del hecho, de tal forma que la concurrencia de esas acciones en el tiempo y en el espacio es fruto de la casualidad ${ }^{98}$; mientras que en la coautoría ambos sujetos se ponen de acuerdo en realizar precisamente la acción peligrosa y superadora del riesgo permitido. Pues bien, empresario y técnico en prevención de riesgos laborales serán coautores en aquellos supuestos en los que habiendo asumido cada uno de ellos la obligación de facilitar parte de los medios necesarios a los trabajadores no lo hacen, siendo la conjunción de ambas conductas, es decir, la ausencia de todos esos medios, lo que determina la producción del peligro y habiéndose puesto de acuerdo en la realización de dichas conductas. Se apreciará autoría accesoria en aquellos casos en los que se realice la conducta referida pero sin que medie acuerdo en su ejecución.

\section{Conclusiones}

1. Podemos afirmar, por varias razones, que el virus del SARS-CoV-2 y los riesgos inherentes, en concreto, el

accesoria, véase GARCÍA DEL BLANCO, M. ${ }^{a}$ V., La coautoría en Derecho penal, Valencia, 2006, pp. 433 ss.; GUTIÉRREZ RODRÍGUEZ, M., La responsabilidad penal del coautor, Valencia, 2001, pp. 261 s. También, en relación con la imprudencia, LUZÓN PEÑA, D. M., "La 'determinación objetiva del hecho'. Observaciones sobre la autoría en delitos dolosos e imprudentes de resultado", Anuario de Derecho Penal y Ciencias Penales, 1989, pp. 899; DÍAZ Y GARCÍA CONLLEDO, M., La autoría en Derecho penal, Barcelona, 1991, pp. 635 s.; ROSO CAÑADILLAS, R., Autoría y participación imprudente, Granada, 2002, p. 593; PAREDES CASTAÑÓN, J.M./RODRÍGUEZ MONTAÑÉS, T., El caso de la colza: responsabilidad penal por productos adulterados o defectuosos, Valencia, 1995, p. 147; RODRÍGUEZ VÁZQUEZ, V., Responsabilidad penal en el ejercicio de actividades médico-sanitarias, Madrid, 2012, pp. 386 ss.

98 Véase GUTIÉRREZ RODRÍGUEZ, M., La responsabilidad penal del coautor, Valencia, 2001, p. 183. 
riesgo de contraer la COVID-19, pueden ser considerados un riesgo laboral y, por lo tanto, deben entenderse abarcados por las normas de prevención de riesgos laborales. En primer lugar, porque el daño que del contagio del virus puede traer causa lo es con motivo u ocasión del trabajo, tal y como se establece en la propia LPRL. Esto, en mi opinión, no ofrece duda alguna a la vista de la enfermedad y sus características, así como su irrupción repentina. Además, en muchas actividades profesionales el propio desempeño laboral, por la naturaleza de la profesión (sanitarias, enseñanza, sector servicios con alta exposición al público), implica ese riesgo de contagio. El segundo motivo es que las normas de prevención de riesgos laborales dictadas por los Poderes públicos para hacer frente a la enfermedad de COVID-19 ponen de manifiesto que el contagio es un riesgo laboral que debe ser objeto de prevención. Baste, a modo de ejemplo, citar en este apartado de conclusiones el documento de referencia en esta materia, el "Procedimiento de actuación para los servicios de prevención de riesgos laborales frente a la exposición al SARS-CoV-2", publicado por el Ministerio de Sanidad por primera vez el día 28 de febrero de 2020, siendo objeto de sucesivas revisiones y actualizaciones desde entonces. Este documento, en cuya redacción ha participado el Ministerio de Trabajo y Economía Social establece que "corresponde a las empresas evaluar el riesgo de exposición en que se pueden encontrar las personas trabajadoras en cada una de las tareas diferenciadas que realizan y seguir las recomendaciones que sobre el particular emita el servicio de prevención, siguiendo las pautas y recomendaciones formuladas por las autoridades sanitarias". A continuación, en función de la naturaleza de las actividades profesionales y de los mecanismos de transmisión del SARS-CoV-2, se establecen los escenarios de exposición en los que se pueden encontrar los trabajadores, clasificándolos en tres niveles de riesgo. En el mismo documento, se recogen las medidas de carácter organizativo, de protección personal (no sólo de equipos de protección 
individual -EPI-), las relativas a trabajadores especialmente sensibles en relación con la infección de SARS-CoV-2 atendiendo al estado de conocimientos de la ciencia médica. El tercer motivo, porque el riesgo de contagio por SARS-CoV-2 se ha interpretado como una causa para aplicar el art. 21 LPRL. Así lo ha considerado expresamente el Ministerio de Trabajo y Economía Social a través de la "Guía para la actuación en el ámbito laboral en relación al nuevo coronavirus". Además de todo lo señalado anteriormente, se deben añadir aquí los pronunciamientos judiciales que ya se han producido sobre esta materia al menos en la jurisdicción del orden de lo social. En este sentido cabe destacar por su precisión, extensión y contundencia argumentativa, la Sentencia del Juzgado de lo Social n. ${ }^{\circ} 1$ de Teruel, Sentencia 60/2020 de 3 de junio de 2020, que concluye que "tanto la LPRL como el RD sobre EPIS, han sido infringidos por las demandadas [scil. Servicio Aragonés de Salud (SAS), al Instituto aragonés de servicios sociales y frente a la Diputación general de Aragón] al no proveerse a los trabajadores y empleados representados por el sindicato FASAMET, de los EPIS adecuados y suficientes para desempeñar su trabajo en condiciones de seguridad, sin riesgo para la seguridad o salud de los trabajadores".

2. La infracción de normas de prevención de riesgos laborales derivados del SARS-CoV-2 puede dar lugar a responsabilidad penal conforme al art. $316 \mathrm{CP}$ o, en su caso, al art. $317 \mathrm{CP}$ en que se recoge la modalidad imprudente. Los "medios" a los que se refiere el art. 316 CP son tanto los materiales (p. ej., equipos individuales y colectivos, instrumentos, herramientas, espacios) como los inmateriales (formación e información), tal y como entiende la mayoría de la doctrina y de los tribunales. En el contexto que nos ocupa, los medios materiales se corresponderían con mascarillas, pantallas protectoras, guantes, líquidos hidroalcohólicos, y cualquier otro medio profiláctico de los establecidos en la normativa desarrollada al respecto (ver supra). Naturalmente, estos medios, muchos de ellos de EPI, tendrán unas especificaciones 
técnicas precisas con diferentes niveles de seguridad en función del tipo de actividad que se desarrolle y la exposición al riesgo que pueda suponer. Junto a estos medios materiales individuales se deben incluir medios inmateriales como los relativos a la información al trabajador sobre las características del SARS-CoV-2, su modo de transmisión, las mejores formas para evitar el contagio. Además, la formación, tanto por lo que respecta al uso de los equipos individuales como al comportamiento respecto a la colectividad (p. ej., en lo que se ha llamado la etiqueta respiratoria). Sin olvidar los medios organizativos que ante el riesgo vinculado al SARS-CoV-2 adquiere mayor importancia. En este sentido la norma sobre la que ha de pivotar la organización del trabajo es el distanciamiento social fijado en 2 metros de perímetro alrededor de cada una de las personas. A partir de aquí se podrán organizar turnos de entrada y salida, turnos de trabajo, reducción de aforos en los lugares de trabajo, ordenación de la circulación de personas en los lugares de trabajo, entre otras. Y, por supuesto, medidas higiénicas y de limpieza estrictas. Todas estas medidas deberán adaptarse a la casuística de cada actividad laboral.

3. La jurisprudencia ha entendido tradicionalmente que el hecho de que el empresario o persona en quien delegue no vigile el uso que los trabajadores hacen de los medios proporcionados constituye una conducta típica de los arts. 316 y 317 CP. Sin embargo, la doctrina mayoritaria, con la que estoy de acuerdo, considera que la literalidad de la expresión "no facilitar los medios necesarios" no abarca la no vigilancia. Esta interpretación del precepto restringe considerablemente el espectro de conductas que pueden verse subsumidas en estos tipos penales.

4. En la materia que nos ocupa, basta con comprobar que la exposición a los riesgos derivados del SARS-CoV-2 por parte del trabajador se produjo en su lugar de trabajo o en el ejercicio de su actividad laboral y que al no contar con 
los medios de protección adecuados conforme a la normativa de prevención de riesgos laborales la posibilidad de que se llegase a infectar y con ello desarrollar la enfermedad de COVID-19 se planteó como real, cierta y próxima. No se requiere un resultado de lesión para la vida, salud o integridad física de los trabajadores. A la vista de los datos se puede concluir que el riesgo que entraña el virus para la salud o incluso la vida es grave, teniendo en cuenta además que no existe ni vacuna ni tratamiento específico.

5. La LPRL, los reglamentos de desarrollo y otras disposiciones normativas despliegan todo su alcance en relación con los riesgos laborales derivados del SARS-CoV-2, viéndose además reforzadas por normas sectoriales promulgadas por el Gobierno con motivo de la pandemia de COVID-19. Nos encontramos ante un delito especial propio, que sólo puede ser cometido por quien tiene obligación legal de facilitar los medios preventivos, lo que, como quedó dicho, corresponden originariamente al empresario (en un sentido material y, por tanto, amplio) y en el ámbito de las Administraciones Públicas a quien tiene atribuidas estas funciones, ocupando una posición directiva relevante. Se discute la relevancia jurídicopenal que puedan presentar las conductas que llevan a cabo los delegados del empresario en materia de prevención de riesgos laborales.

6. En relación con los técnicos en prevención de riesgos laborales integrados en servicios externos de prevención contratados por la empresa, la mayoría de la doctrina entiende que pueden ser considerados de entrada posibles sujetos activos del delito contemplado en el art. 316 (o, en su caso, del art. 317 CP). Sin embargo, en mi opinión, estos técnicos no tienen, con carácter general, las condiciones exigidas por el tipo para ser autores. De acuerdo con la LPRL y con el RD 39/1997, se trata de profesionales que llevan a cabo una función de asesoramiento en materia de prevención pero que no disponen de recursos y de autonomía para proporcionar 
los medios de seguridad necesarios a los trabajadores. Así, entendiendo como vertical la división de trabajo que media entre el empresario y los técnicos en prevención de riesgos laborales, siendo el primero superior jerárquico frente al segundo, en raras ocasiones se podría apreciar la responsabilidad penal del técnico de prevención. Sólo en caso de que el empresario no proporcione los medios necesarios debido a un error provocado por una incorrecta evaluación de riesgos o planificación de la actividad preventiva por parte de los responsables de los servicios de prevención contratados, pudiendo confiar en la actuación de estos últimos, se podría exigir responsabilidad penal de los técnicos en prevención como autores mediatos del art. 316 o del art. $317 \mathrm{CP}$, en función de si su conducta fuese dolosa o imprudente. Ahora bien, las cosas cambian desde el momento en que los técnicos en prevención no sólo desempeñen las tareas de evaluación y planificación de las medidas preventivas en una empresa, si no cuando a través del concierto firmado con la empresa asuman directamente las funciones de prevención, es decir, se obliguen a proporcionar todos o parte de los medios preventivos a los trabajadores de la empresa lo que significará que dispondrán de autonomía de decisión y de gestión, al menos en lo que a esta parcela se refiere, en el seno de la empresa que los contrata. En este sentido, los técnicos de prevención que asumen tareas de formación e información de los trabajadores en materia de prevención de riesgos laborales derivados del SARS-CoV-2 y la enfermedad vinculada, pueden llegar a incurrir directamente en responsabilidad penal como autores del art. $316 \mathrm{CP}$ o art. $317 \mathrm{CP}$ en caso de que no cumplan o lo hagan inadecuadamente con dichas funciones. También cabría exigirles responsabilidad penal en los casos en que no diseñen correctamente los planes de prevención necesarios para eliminar o minimizar el riesgo de contagio en el centro de trabajo, aunque no sean ellos los encargados directamente de implementarlos o ejecutarlos. 


\section{Bibliografía}

ABRAHAM, T., Twenty-first century plague. The story of SARS, Hong Kong University Press, Hong Kong, 2004.

ALPACA PÉREZ, A., Delitos tributarios y aduaneros, Ubi Lex, Lima, 2015.

AGUADO LÓPEZ, S., El delito contra la seguridad en el trabajo: artículos 316 y 317 del Código Penal, Valencia, Tirant lo Blanch, 2002.

ARABI, Y. M./BALKHY, H. H./HAYDEN, F. G./BOUCHAMA, A./LUKE, T./BAILLIE, K./AL-OMARI, A./HAJEER, A. H./SENGA, M./DENISON, M. R./ NGUYEN-VAN-TAM， J. S./SHINDO, N./BERMINGHAM, A./CHAPPELL, J. D./VAN KERKHOVE, M. D./FOWLER, R. A., "Middle East Respiratory Syndrome", N Engl J Med 376;6, February 9, 2017, pp. 584-594. https://doi.org/10.1056/NEJMsr1408795

ARROYO ZAPATERO, L., La protección penal de la seguridad en el trabajo, Madrid, Servicio Social de Higiene y Seguridad del Trabajo, 1981.

ARROYO ZAPATERO, L., Manual de Derecho Penal del Trabajo, Barcelona, Praxis, 1988.

BLASCO PELLICER, A./LÓPEZ BALAGUER, M./ALEGRE BUENO, M./RAMOS MORAGUES, F./TALÉNS VISCONTI, E., Análisis normativo de las medidas laborales y de Seguridad Social frente a la crisis del COVID-19, Tirant lo Blanch, Valencia, 2020.

BOLEA BARDON, C., Autoría mediata en Derecho penal, Valencia, Tirant lo Blanch, 2000.

CORCOY BIDASOLO, M./CARDENAL MONTRAVETA, S./HORTAL IBARRA, J. C., "Protección penal de los accidentes laborales", Revista del Poder Judicial, 2003, n. ${ }^{\circ} 71,39-68$.

DE VICENTE MARTÍNEZ, R., "Sujetos responsables de la seguridad y salud laboral en el trabajo en el ámbito laboral y en el ámbito penal. En especial la responsabilidad penal de los técnicos en prevención de riesgos laborales", Actualidad Penal, 2003, n. ${ }^{\circ}$ 1, 333-356. 
DE VICENTE MARTÍNEZ, R., Derecho penal del trabajo. Los delitos contra los derechos de los trabajadores y contra la Seguridad Social, Tiran lo Blanch, Valencia, 2020.

DE VICENTE MARTÍNEZ, R., Seguridad en el trabajo y Derecho penal, Barcelona, Bosch, 2001.

DÍAZ Y GARCÍA CONLLEDO, M., "El delito contra la seguridad en el trabajo: algunos problemas del dolo y la imprudencia, concursales y relativos al art. 318 del Código Penal”, Poder Judicial, n. ${ }^{\circ}$ 80, 2005, 11-54.

DÍAZ Y GARCÍA CONLLEDO, M., "La autoría en Derecho penal. Caracterización general y especial atención al Código Penal colombiano", Derecho Penal y Criminología, 2004, 33-65.

DÍAZ Y GARCÍA CONLLEDO, M., "La autoría mediata. Con una especial referencia a los delitos socioeconómicos y contra el medio ambiente", Documentos Penales y Criminológicos, 2001, . $^{\circ} 1,29-60$.

DÍAZ Y GARCÍA CONLLEDO, M., "La influencia de la teoría de la autoría (en especial de la coautoría) de Roxin en la doctrina y en la jurisprudencia españolas. Consideraciones críticas", Revista Nuevo Foro Penal, n. ${ }^{\circ} 76,15-48$.

DÍAZ Y GARCÍA CONLLEDO, M., La autoría en Derecho Penal, Barcelona, PPU, 1991.

DÍAZ Y GARCÍA CONLLEDO, M./DE VICENTE REMESAL, J., "Autoría o participación en determinados supuestos de 'vigilancia' (comentarios a la STS de 21 de febrero de 1989) (Pte. Bacigalupo Zapater)", Poder Judicial, 1992, n. ${ }^{\circ} 27,189-216$.

DÓPICO GÓMEZ-ALLER, J., “¿Qué salvar del art. 318 CP? La responsabilidad de administradores y encargados del servicio en los delitos contra los derechos de los trabajadores 'atribuidos a una persona jurídica'. Consideraciones de lege ferenda", en ÁLVAREZ GARCÍA, F. J. (Dir.), La adecuación del Derecho 
penal español al ordenamiento de la Unión Europea. La Política criminal europea, Valencia, Tirant lo Blanch, 2008, 551-577.

DURÁN SECO, I., La coautoría en Derecho Penal: aspectos esenciales, León, Secretariado de publicaciones y medios audiovisuales de la Universidad de León, 2003.

FIGUEROA NAVARRO, M. C., "La responsabilidad penal por infracción de las normas de prevención de riesgos laborales", La Ley Penal, 2005, n. ${ }^{\circ}$ 19, 51-64.

FRANCÉS LECUMBERRI, P., El desvalor penal de la contabilidad creativa y otras problemáticas a la luz del bien jurídico protegido en el art. 290 CP, Tirant lo Blanch, Valencia, 2017.

GANDHI, M./YOKOE, D./HAVLIR, D. V., "Asymptomatic transmission, the Achilles' heel of current strategies to control Covid-19", $N$ Eng J Med, April 27, 2020, pp. 1-3. https://doi.org/10.1056/NEJMe2009758

GANDHI, R./LYNCH, J./DEL RIO, C., "Mild or Moderate Covid-19", $N$ Engl J Med 383;16, April 24, 2020, pp. 1-9. https://doi.org/10.1056/NEJMcp2009249

GARCÍA DEL BLANCO, M. V., La coautoría en Derecho penal, Valencia, Tirant lo Blanch, 2006.

GARCÍA FIGUEROA, F., Los sujetos activos de los delitos contra la seguridad y salud en el trabajo. Especial consideración al sector de la construcción (Tesis doctoral), Getafe, 2011.

GARCÍA MOSQUERA, M., La estafa de seguro, La Ley, Madrid, 2006.

GÓMEZ MARTÍN, V., "El enigmático art. 318 CP: diez cuestiones controvertidas", en MIR PUIG, S./CORCOY BIDASOLO, M. (dirs.), HORTAL IBARRA, J. C. (coord.), Protección penal de los derechos de los trabajadores: seguridad en el trabajo, tráfico ilegal de personas e inmigración clandestina, Madrid, Edisofer, 2009, 227-280.

GUANARTEME SÁNCHEZ LÁZARO, F., Intervención delictiva e imprudencia, Granada, Comares, 2004. 
GUTIÉRREZ RODRÍGUEZ, M., La responsabilidad penal del coautor, Valencia, Tirant lo Blanch, 2001.

HERNÁNDEZ MARTÍNEZ, G., "SARS: epidemiología y mecanismos de transmisión", Med Intensiva 2003; 27 (10), pp. 686-91. https://doi.org/10.1016/s0210-5691(03)79993-8

HERNÁNDEZ PLASENCIA, J. U., La autoría mediata en Derecho penal, Granada, Comares, 1996.

HORTAL IBARRA, J. C., "Delimitación del riesgo típico en el delito contra la seguridad en el trabajo (art. 316 $\mathrm{CP}$ ): especial atención a la relevancia jurídico-penal de la infracción del deber de vigilancia”, Cuadernos de Política Criminal, 2008, n. ${ }^{\circ}$ 96, 73-99.

HORTAL IBARRA, J. C., "Legitimación y eficacia de la intervención penal en el ámbito de la prevención de riesgos laborales", en MIR PUIG, Santiago/CORCOY BIDASOLO, M. (dirs.), GOMÉZ MARTÍN, Víctor (coord.), La Política Criminal en Europa, Barcelona, Atelier, 2004, 237-252.

HORTAL IBARRA, J. C., Protección penal de la seguridad en el trabajo: una aproximación a la configuración del Derecho penal en la "sociedad del riesgo", Barcelona, Atelier, 2005.

LASCURAÍN SÁNCHEZ, J. A., "Aspectos constitucionales del Derecho penal del trabajo", Cuadernos de Derecho Judicial, 2008, n. ${ }^{\circ}$ 5, 301-329.

LASCURAÍN SÁNCHEZ, J. A., "La imputación penal del accidente de trabajo", en AA.VV, Tutela penal de la seguridad en el trabajo, Cuaderno penales José María Lidón, Bilbao, Universidad de Deusto, 2006, 41-64.

LASCURAIIN SÁNCHEZ, J. A., "La prevención penal de los riesgos laborales: cinco preguntas", en CARBONELL MATEU, J. C./DEL ROSAL BLASCO, B./ MORILLAS CUEVA, L./ORTS BERENGUER, E./ QUINTANAR DÍEZ, M. (coords.), Estudios Penales en Homenaje al profesor Cobo del Rosal, Madrid, Dykinson, 2005, 565-592. 
LASCURAÍN SÁNCHEZ, J. A., La protección penal de la seguridad e higiene, Madrid, Civitas, 1994.

NAVARRO CARDOSO, F./LOSADA QUINTÁS, J., "La autoría en los delitos contra la seguridad e higiene en los trabajos", Actualidad Penal, 2001, n. ${ }^{\circ}$ 40, 965-965.

LUZÓN PEÑA, D. M., "Autoría e imputación objetiva en el delito imprudente: valoración de las aportaciones causales (Comentario a la STS de 27 de enero de 1984)", Revista de Derecho de la Circulación, 1984.

LUZÓN PEÑA, D. M., "La 'determinación objetiva del hecho'. Observaciones sobre la autoría en delitos dolosos e imprudentes de resultado", Anuario de Derecho Penal y Ciencias Penales, 1989, Tomo 42, 889-913.

LUZÓN PEÑA, D. M./DÍAZ Y GARCÍA CONLLEDO, M., "Determinación objetiva y positiva del hecho y realización típica como criterios de autoría", Anuario de la Facultad de Derecho de la Universidad de Alcalá de Henares, 2000, n. ${ }^{\circ}$ 8, 53-88.

LUZÓN PEÑA, D. M./DÍAZ Y GARCÍA CONLLEDO, M., "Determinación objetiva y positiva del hecho y realización típica como criterios de autoría", Revista de Derecho Penal Contemporáneo, 2003, n. ${ }^{\circ}$ 2, 89-128.

LUZÓN PEÑA, D. M./DÍAZ Y GARCÍA CONLLEDO, M., "Objektive positive Tatbestimmung und Tabestandsverwirklichung als Täterschaftsmerkmale", en Bernd SCHUNEMANN (dir.), Festschrift für Claus Roxin, Berlin, New York, de Gruyter, 2001.

MARTÍN LORENZO, M./ORTIZ DE URBINA GIMENO, I., "Guía InDret penal de la jurisprudencia sobre responsabilidad por riesgos laborales", InDret, 2009, n. ${ }^{\circ}$ 2, 1-62. MARTÍN LORENZO, M./ORTIZ DE URBINA GIMENO, I., "Los delitos contra los trabajadores en el ámbito de la construcción", en POZUELO PÉREZ, L. (coord.), Derecho penal de la construcción: aspectos urbanísticos, inmobiliarios y de seguridad en el trabajo, Granada, Comares, 2006, 319-499. 
MARTÍNEZ-BUJÁN PÉREZ, C., "Delitos contra los derechos de los trabajadores. Delitos contra los derechos de los ciudadanos extranjeros”, en GONZÁLEZ CUSSAC, J. L. (coord.), Derecho penal Parte Especial, Tirant lo Blanch, Valencia, 6. ${ }^{\text {a }}$ ed., 2019.

MARTÍNEZ-BUJÁN PÉREZ, C., Derecho penal económico y de la empresa, Parte especial, 6. ${ }^{\text {a }}$ ed., Tirant lo Blanch, Valencia, 2019.

MORALES GARCÍA, O., "Régimen de responsabilidad penal derivada de la siniestralidad laboral en la ejecución de obras civiles", Actualidad Jurídica Uría Menéndez, 2005, n. ${ }^{\circ} 12,31-45$.

MORALES HERNÁNDEZ, M. A., "Delitos contra los derechos de los trabajadores", en MARÍN DE ESPINOSA CEBALLOS, E. (dir.)/ESQUINAS VALVERDE, P. (coord.), Lecciones de Derecho penal. Parte especial, Tirant lo Blanch, Valencia, 2018.

MUÑOZ CONDE, F., Derecho penal, Parte especial, 22. ${ }^{\text {a }}$ ed., Tirant lo Blanch, Valencia, 2019.

NAVAS-PAREJO ALONSO, M., "El papel de los arquitectos como responsables de los delitos contra la seguridad y salud de los trabajadores: la relevancia del análisis de su conducta", Aranzadi Social, 2011, n. ${ }^{\circ}$, 203-218.

NÚÑEZ CASTAÑO, E., "Delitos contra los derechos de los trabajadores", en GALÁN MUÑOZ, A./NÚÑEZ CASTAÑO, E., Manual de Derecho penal económico $y$ de la empresa, 3. ${ }^{\mathrm{a}}$ ed., Tirant lo Blanch, Valencia, 2019.

OLAIZOLA NOGALES, I., "Delitos contra los derechos de los trabajadores (arts. 316 y $317 \mathrm{CP}$ ) y su relación con los resultados lesivos", InDret, 2010, n. ${ }^{\circ}$ 2, 1-52.

PAREDES CASTAÑÓN, J. M./RODRÍGUEZ MONTANÉS, T., El caso de la colza: responsabilidad penal por productos adulterados o defectuosos, Valencia, Tirant lo Blanch, 1995. 
PAVÍA CARDEL, J., "Responsabilidad penal por el siniestro laboral: una guía para la imputación personal", $L a$ Ley Penal, 2005, n. ${ }^{\circ}$ 19, 17-50.

PEIRIS, J. S.M./YUEN, K. Y./OSTERHAUS, A. D.M.E./ STÖHR, K., "The severe acute respiratory sindrome", N ENGL J MED 349;25, December 18, 2003, pp. 2431-41.

PÉREZ MANZANO, M., Autoría y participación imprudente en el Código penal de 1995, Madrid, Civitas, 1999.

PÉREZ-SAUQUILLO MUÑOZ, C., "Reflexiones y críticas sobre el pensamiento de la acumulación", en $L L P$ 2017-128, págs. 1-32.

REVELLES CARRASCO, M., "El delito contra la vida y la salud de los trabajadores al hilo de la Sentencia de la Audiencia Provincial de Madrid de 20 de julio de 2006", Revista de Derecho Social, 2006, n. ${ }^{\circ} 38,177-$ 190.

RODRÍGUEZ VÁZQUEZ, V., Responsabilidad penal en el ejercicio de actividades médico-sanitarias, Marcial Pons, Madrid, 2012, págs. 337 ss.

RODRÍGUEZ VÁZQUEZ, V., "Análisis de la responsabilidad penal de los técnicos en prevención de riesgos laborales, recursos preventivos y coordinadores de seguridad, a la luz de los arts. 316 y 317 del Código Penal”, La Ley Penal, $n .^{\circ}$ 103, julio-agosto 2013, pp. 51-68.

RODRÍGUEZ VÁZQUEZ, V., "Democracia, sistemas de control y Derecho penal. Aproximación al fenómeno del soft law y de la externalización de los deberes estatales de control a través de los compliance programs", Revista Electrónica de Ciencia Penal y Criminología, núm. 22-11, 2020, pp. 1-48.

ROSO CAÑADILLAS, R., Autoría y participación imprudente, Granada, Comares, 2002.

SALVADOR, N./PEÑALOSA, C., "Responsabilidad empresarial por contagio", Diario La Ley, N. ${ }^{\circ} 9631$, 2020, pp. 1-6. 
SERRANO-PIEDECASAS FERNÁNDEZ, J. R., "La responsabilidad penal del empresario, personal técnico y de los servicios de prevención en los delitos contra la seguridad e higiene en el trabajo", Revista Penal, 2002, n. ${ }^{\circ} 10,94-111$.

TERRADILLOS BASOCO, J., "Respuesta penal frente a la siniestralidad laboral", en AA.VV, Tutela penal de la seguridad en el trabajo, Cuadernos penales José María Lidón, Bilbao, Universidad de Deusto, 2006, 15-41.

TERRADILLOS BASOCO, J., Delitos contra la vida y la salud de los trabajadores, Valencia, Tirant lo Blanch, 2002.

TERRADILLOS BASOCO, J., La siniestralidad laboral como delito, Albacete, Bomarzo, 2006.

TORRES CADAVID, N., La responsabilidad penal del asesor fiscal. Problemas de autoría y participación en el delito de defraudación tributaria, Tirant lo Blanch, Valencia, 2019.

VAN DOREMALEN, N./MORRIS, D. H./HOLBROOK, M. G. et al., "Aerosol and surface stability of SARSCoV-2 as Compared with SARS-CoV-1", $N$ Engl $J$ Med 382;16, April 16, 2020, pp. 1-4. https://doi. org/10.1056/NEJMc2004973

VAQUÉ RAFART, J., "Síndrome respiratorio agudo grave (SARS)", An Pediatr (Barc) 2005; 62 (Supl 1), pp. 6-11.

WEBER, S. G./BOTTEI, Ed./COOK, R./O'CONNOR, M., "SARS, emerging infections, and bioterrorism preparedness", The Lancet, Infectious Diseases Vol. 4 August 2004, pp. 482-484. https://doi.org/10.1016/s14733099(04)01098-9

World Health Organization (WHO), Coronavirus disease 2019 (COVID-19). Situation Report-39, 28 February 2020, https://www.who.int/docs/default-source/ coronaviruse/situation-reports/20200228-sitrep-39-covid-19.pdf?sfvrsn=5bbf3e7d_4 (consultado en: 10/05/2020). 
World Health Organization(WHO), Coronavirus disease 2019 (COVID-19). Situation Report-50, 10 March 2020, https://www.who.int/docs/default-source/coronaviruse/situation-reports/20200310-sitrep-50-covid-19. pdf?sfvrsn=55e904fb_2 (consultado en: 10/05/2020).

World Health Organization (WHO), Coronavirus disease 2019 (COVID-19). Situation Report-51, 11 March 2020, https://www.who.int/docs/default-source/ coronaviruse/situation-reports/20200311-sitrep-51-covid-19.pdf?sfvrsn=1ba62e57 10 (consultado en: 10/05/2020).

World Health Organization (WHO), Novel Coronavirus (2019-nCoV). Situation Report-12, 1 February 2020, https://www.who.int/docs/default-source/coronaviruse/situation-reports/20200201-sitrep-12-ncov.pdf?sfvrsn=273c5d35 2 (consultado en: 10/05/2020).

ZÚÑIGA RODRÍGUEZ, L., "Problemas de responsabilidad (penal, administrativa y civil) en el ámbito empresarial por accidentes de trabajo", Revista electrónica de Ciencia penal y Criminología, 2008, n. ${ }^{\circ}$ 10, 1-15. 